\title{
ÁLVARO PAIS, MARSÍLIO DE PÁDUA E O ARTIGO 68 DO LIVRO PRIMEIRO DO ESTADO E PRANTO DA IGREJA
}

\author{
José Antônio de C. R. de Souza*
}

SÍNTESE - Em boa parte do Artigo 68 do Livro Primeiro de seu Estado e Pranto da Igreja, Álvaro Pais, O. Min. (c. 1270-1349) refuta 5 proposições com implicações políticas atribuídas a Marsílio de Pádua (1280-1342). Neste artigo, analisamos a refutação dessas proposições feitas pelo Menorita galego, comparando-as, de um lado, com os textos, efetivamente escritos pelo Médico paduano, que se encontram em sua obra Defensor da Paz (1324) e, de outro, cotejando-o com uma Epistula ad quosdam cardinales, de autoria do mencionado Frade, escrita pelo menos dois anos antes. Desse estudo resultaram as seguintes conclusões: 1 - Frei Álvaro, sem fazer nenhuma alusão, apoiou-se basicamente na mencionada Epistula. 2 - Sob 0 aspecto doutrinal, essencialmente, não há diferença entre ambos os textos alvarinos. 3 - Nos dois textos, o Franciscano galego não compulsou o Defensor da Paz, tendo utilizado as teses que os censores dessa obra imputaram ao seu autor; em 1327, quando o Papa João XXII condenou-a como herética.

PALAVRAS-CHAVE - Álvaro Pais. Marsílio de Pádua. Plenitude do poder. Filosofia política.
ABSTRACT - In a large part of the Article 68 of the Book one of his Status et Planctus Ecclesiae, Alvarus Pelagius O. Min. (c. 1270-1349) refutes five propositions, having political implications, attributed to Marsilius Patavinus (1280-1342). In this study, we analyze the refutation of these propositions made by Alvarus, comparing, on the one hand, with the texts, really, written by Marsilius, which are in his book entitled Defensor pacis (1324), and on the other hand, quoting Alvarus' text with the Epistula ad quosdam cardinales, also written by the mentioned Franciscan friar two years before. From this study, resulted the following conclusions: 1 - Without to do any mention in the Article 68, the principal Alvarus' source was the referred Epistula. 2 - Considering the two texts written by Fr. Alvarus, according the doctrinal aspect, they are essentially equal. 3 - In both texts we could see that Alvarus not had in his hands the Defensor Pacis, having used the thesis which the censors of this book imputed to Marsilius in 1327, when this book was condemned as heretic by the Pope John XXII.

KEY WORDS - Alvarus Pelagius. Marsilius of Padua. Plentitude of power. Political philosophy.

Em boa parte do Artigo 68 do Livro Primeiro do Estado e Pranto da Igreja, ${ }^{1}$ cuja 1ํㅡㄹ redação foi escrita e concluída entre 1330-32, ${ }^{2}$ Frei Álvaro Pais O. Min. ${ }^{3}$ (c.

\footnotetext{
Professor Titular da Universidade Federal de Goiás, Goiânia, Brasil; doutor em História Medieval pela Universidade de São Paulo (USP), 1980, e em História da Filosofia e da Cultura Portuguesa (Medieval), pela Universidade Nova de Lisboa, 2001. Fundador e $1^{10}$ presidente da Comissão Brasileira de Filosofia Medieval, CBMF.
}

\begin{tabular}{|l|l|l|l|l|l|}
\hline VERITAS & Porto Alegre & v. 51 & n. 3 & Setembro 2006 & p. 75-98 \\
\hline
\end{tabular}


1270-1349) refuta cinco teses, com implicações políticas, que atribui a Marsílio de Pádua $^{4}$ (1280-1342), autor do Defensor da Paz, ${ }^{5}$ as quais estariam escritas nessa obra, a mais contundente e dura refutação da hierocracia pontifícia àquela época.

As mencionadas proposições são as seguintes, a 1ㄹ: "...J. Agora quanto à objecção do novel heresiarca, Marsílio de Pádua, de que Pilatos julgou Cristo e assim também o imperador pode julgar o papa..."; a 2‥ "...L. Em seguida, aquele enorme ímpio dogmatiza que qualquer presbitero tem tanto poder como o papa..."; a 3a․ "...P. Diz também aquele pérfido Marsílio que, vagando o papado, sucede o imperador..."; a 4" "... Q. Além disso, a afirmação daquele ímpio doloso e sofista de que a Igreja não pode ter bens temporais é falsa..."; a 5a.: “...Finalmente, a afirmação do dito herege Marsílio de que Cristo, quando subiu aos céus, não deixou vigário, é falsa e herética...". ${ }^{6}$

No âmbito da grande disputa teórica em torno das relações de poder, entre o Papado e Império, tendo com protagonistas, João XXII (1316-34) e Ludovico IV (1314-47), imperador Romano-Germânico, é de per si evidente, a relevância política de tais proposições.

Já tivemos a ocasião de comprovar? que, noutra ocasião, numa carta intitulada Epistula ad quosdam cardinales de potestate pape, de 02 de fevereiro de $1328,{ }^{8}$

Estado e Pranto da Igreja, edição bilíngüe e tradução do latim para o português por Miguel Pinto de MENESES, vol. III, INIC, Lisboa, 1991, p. 337-353.

2 Op. cit., vol. VIII, 1998, p. 435: "Concluí esta obra, com a graça de Deus, correndo o ano do Senhor de 1332...e comecei-a no ano do Senhor de 1330... Por mão própria corrigi e apostilei esta obra duma vez no ano do Senhor de 1335 no Algarve de Portugal, onde sou prelado, na vila de Tavira. E segunda vez corrigi-a e apostilei-a em Santiago de Compostela no ano do Senhor de 1340".

3 Sobre a vida do Menorita galego cf., "Um fillo de Gómez Chariño: Álvaro Pais; traxectoria e promocion al episcopado", Revista Galega do Ensino, Santiago de Compostela, 44 (2004): 177-197; Idem, "D. Álvaro Pelayo O. Min. y D. Alfonso IV de Portugal y las relaciones de poder", in Anales del Seminario de Historia de la Filosofía, Madrid, Un. Complutense, 20 (2003): 51-67. Quanto ao pensamento político de Álvaro Pais, numa perspectiva mais abrangente, cf. João Morais BARBOSA, O De Statu et Planctu Ecclesiae Estudo Crítico, Lisboa, Universidade Nova de Lisboa, 1982; Marino DAMIATA OFM, Alvaro Pelayo Teocratico Scontento, Firenze, Ed. Studi Francescani, 1984; N. IUNG, Un Franciscain Théologien du Pouvoir Pontifical au XIVe Siècle: Alvaro Pelayo, Évêque et Penitencier de Jean XXII, Paris, J.Vrin, 1931.

4 Especialmente no último quartel, a bibliografia sobre o Médico paduano e seu pensamento político é extensa. Baste mencionar, por exemplo, os volumes V (1979) e VI (1980) de Medio Evo, organizados por Gregorio PIAIA; Marino DAMIATA OFM, Plenitudo Potestatis e Universitas Civium in Marsilio da Padova, Firenze, ed. Studi Francescani, 1983. Carlo DOLCINI, Introduzione a Marsilio da Padova, $2^{a}$ ed., Roma, Laterza, 1999. Sérgio R. STREFLING, Igreja e Poder Plenitude do Poder e Soberania Popular em Marsílio de Pádua, Coleção Filosofia vol. 146, Porto Alegre, EDIPUCRS, 2002; Floriano Jonas CESAR, Papado, império e o pensamento de Marsílio de Pádua, São Paulo, Pósgraduação em Filosofia, USP, tese de doutoramento, mimeo, 2000.

5 In Clássicos do Pensamento Político, vol.12, tradução e notas por José Antônio de C. R. de SOUZA, Petrópolis, Vozes, 1997, 701 páginas. Introdução, Gregorio PIAIA, F. BERTELLONI e J. Antônio de C. R. de SOUZA.

6 Cf., respectivamente, p. 337; p. 339; p. 345; p. 347; p. 349

Cf. José Antônio de C. R. de SOUZA, "Algumas considerações acerca duma carta de Álvaro Pais O.M. (1270-1349), datada de 1328", in Pensamiento Medieval Hispano, Homenaje a Horacio Santiago-Otero, (José María Soto Rábanos, Coordinador), Madrid, CSIC/Consejería de educación y cultura de la junta de Castilla y León, Diputación de Zamora, 1998, vol. II, p. 1175-1201. Aí também traduzimos os passos mais relevantes dessa Carta e os usaremos neste estudo. 
o Menorita galego tinha refutado essas proposições e que, efetivamente, elas não se encontram ad litteram no Defensor da Paz. ${ }^{9}$

Pretendemos, pois, com este trabalho, verificar se Álvaro Pais utilizou como fonte imediata ou não a predita Epistula ao escrever o Artigo em apreço; se neste Artigo 68 ampliou ou não seu pensamento acerca das preditas proposições e, se, desta vez, ao refutá-las, compulsou ou não o Defensor da Paz.

Ora bem, como ponto de partida, convém saber o que o Médico patavino escreveu em seu tratado que possa ter alguma conexão com aquelas proposições que lhe foram imputadas pelo Franciscano galego.

Quanto à $1^{a}$ proposição, de fato, inúmeras vezes, Marsílio sustentou, em sua referida obra, que: (a) Jesus Cristo, o Filho de Deus feito homem, se submeteu ao julgamento e à condenação da autoridade secular então constituída, Pôncio Pilatos, embora tivesse sido injustamente acusado pelos judeus, perante o Governador da Palestina, porque não tinha vindo a este mundo para estabelecer um reino temporal e ser o seu governante. ${ }^{10}$ (b) Igualmente, com respeito às autoridades

8 Cf. V. MENEGHIN, Scriti Inediti di Fra Alvaro Pais, Lisboa, Instituto de Alta Cultura da Universidade de Lisboa, 1969, texto: 96-132.

9 Introdução ao Defensor da Paz p. 43 “...a obra foi examinada e refutada por solicitação do próprio Papa João XXII. Entre os teólogos convidados para executar esse mister estavam o agostiniano Guilherme Amidani de Cremona, e o carmelita Siberto de Beek; a estes nonnuli viri catholici se juntou por auto-iniciativa, o premonstratense Pedro de Lutra, a quem se deve talvez, a formulação dos erros pontuados no texto marsiliano. O fruto desse trabalho resultou na bula Licet Iuxta Doctrinam, sancionada em 27 de outubro de 1327, na qual vêm incriminadas e condenadas cinco preposições, que não estão diretamente hauridas no texto do Defensor da Paz, mas secundum sensum.. Trata-se das mais radicais teses eclesiológico-políticas apresentadas na Secunda dictio: 1) Todos os bens temporais da Igreja estão sujeitos ao controle do Imperador. 2) Cristo não deixou nenhum chefe para a Igreja e S. Pedro não teve nenhuma autoridade sobre os demais Apóstolos. 3) Cabe ao Imperador corrigir e eventualmente destituir o Papa. 4) Todos os sacerdotes, inclusive o Papa, possuem autoridade igual. 5) Nem o Papa nem a Igreja podem exercer o poder coercivo, salvo se o Imperador Ihes atribuir tal competência...".

${ }_{10}$ Defensor da Paz II, IV, § 4. p. 234: “...Cristo, de acordo com sua intenção e objetivo, através de suas palavras e exemplos, quis se eximir e de fato se eximiu a Si próprio, bem como os seus Apóstolos de exercer todo e qualquer poder governamental e a jurisdição contenciosa ou fazer julgamentos coercivos.

Esse fato é evidente, em primeiro lugar, numa passagem do Evangelho de João, capítulo XVIII [36], onde, Cristo tendo sido acusado perante Pôncio Pilatos, vigário do Imperador Romano para a Judéia, de haver-se intitulado rei dos judeus, respondendo à pergunta do Governador, se Ele tinha dito tal coisa, isto é, se era rei dos judeus, lhe disse: 'Meu reino não é deste mundo', como se quisesse dizer: Eu não vim a este mundo para exercer um poder ou um domínio temporal, da maneira como governam os reis deste mundo.

O próprio Cristo ofereceu imediatamente em seguida uma prova cabal do que acabava de afirmar, declarando: 'Se o meu reino fosse deste mundo, meus súditos com certeza teriam combatido para eu não ser entregue aos judeus', como se quisesse dizer: se tivesse vindo a este mundo para governar um reino temporal e exercer um poder coercivo e terreno,contaria com vassalos desse reino à minha disposição, isto é, com pessoas para combater em meu favor e coibir os transgressores de minhas ordens, como o possuem os outros reis, mas não tenho esses vassalos, como o podes ver claramente...".

[p. 235] "Eis, pois, que tipo de reino Cristo veio ensinar e organizar neste mundo. Trata-se daqueles atos mediante os quais se alcança o reino eterno, isto é, os atos de fé e a prática das outras virtudes teológicas, entretanto, não constrangendo ninguém a fazer isso, como teremos ocasião de ver mais adiante...". 
seculares, os Apóstolos também não só procederam de modo idêntico ao Mestre, mas também ensinaram a todos os cristãos, clérigos e leigos, que este devia ser o modo correto de se comportarem. ${ }^{11}$ (c) Devido a esses fatos, baseados no Novo Testamento e nos comentários dos santos exegetas a essas passagens, não compete a nenhum sacerdote, inclusive ao Papa, exercer qualquer espécie de poder coercivo sobre ninguém, clérigo ou leigo, ainda que se trate de assuntos considerados de natureza espiritual, porque a competência, para tanto, é da alçada exclusiva das autoridades seculares, posto que para isso foram instituídas. Daí, por extensão, terem elas o direito e o dever de julgar e condenar qualquer clérigo,

[p. 236] § 6- "Portanto, através do que foi dito, fica evidente que Cristo não veio a este mundo para organizar um reino temporal ou segundo a carne, e para proferir julgamentos coercivos, mas antes, para edificar um reino espiritual ou celeste, porque só falava e quase sempre pregava a respeito deste último, de acordo com o que consta patentemente do texto evangélico, considerado tanto em seu significado literal quanto místico...".

[p. 245] § 12- " Entretanto, dado que essa opinião se sustenta com mais base no Evangelho de João, capítulo XIX [9-11], iremos propositadamente citá-la abaixo. Quando, pois, Cristo foi conduzido perante Pilatos, vigário de César, como seu juiz, e igualmente acusado de que se fazia passar por rei dos judeus e Filho de Deus, o Governador lhe perguntou: 'De onde és tu?' E como Jesus não lhe deu nenhuma resposta, Pilatos Lhe disse o seguinte, aliás muito consoante ao nosso propósito, cuja citação transcrevemos: 'Não me respondes ? Não sabes que eu tenho poder para te crucificar e para te libertar? Jesus respondeu: Não terias poder algum sobre mim, se não te houvesse sido concedido do alto'.

Eis aqui como Jesus não negou que Pilatos tinha o pode de O julgar e de efetivar tal ato sobre Ele, nem tampouco declarou: isto não te compete de direito, se bem que o fazes de fato, mas ao contrário, Cristo ainda acrescentou que Pilatos tinha esse poder porque lhe tinha 'sido concedido do alto'...".

[p. 246] "Logo, o poder de Pilatos, vindo de Deus, e exercido sobre a pessoa de Cristo foi judiciário e coercivo, como Ele próprio o confessou abertamente...".

11 Marsílio dedica todo o capítulo V, da $2^{\text {a }}$ Parte, ed. cit., p. 251-271, a demonstrar essa tese. Com o fito de abreviar, baste dizer que em favor da mesma, entre outras passagens do Novo Testamento, ele cita (cf. § 1, p. 251) um trecho da 2aㅡ Epístola a Timóteo, 2, 4, em que Paulo diz: 'Ninguém, engajando-se no exército de Deus, se deixa envolver pelas questões seculares'; o conhecido passo da Carta aos Romanos 13, 1-7 (cf. § 4, p. 256); a passagem da 1a Carta a Timóteo, 2, 1-2, (cf. § 7, p. 265) em que o Apóstolo recomenda que se façam orações pelas autoridades constituídas 'a fim de que levemos uma vida calma e tranqüila'; cita, outrossim, (cf. § 8, p. 268) a $1^{\text {a }}$ Canônica de Pedro, II, 13-15, em que ele estabelece que todos devem obediência às autoridades constituídas, porque elas existem, conforme a disposição divina, "para a punição dos malfeitores e para o louvor dos que fazem o bem, pois esta é a vontade de Deus'. E, ainda, para fundamentar seu discurso, lança mão dos comentários dos Padres, constantes das Glosas. Enfim, o Paduano conclui suas considerações sobre esse assunto, afirmando [p. 269]: “...Notai, portanto, como os bem-aventurados Apóstolos Pedro e Paulo estão de acordo ao afirmar que os reis e os governantes foram enviados por Deus 'para castigar os malfeitores', quer dizer, para puni-los neste mundo, mediante o poder coercivo que possuem. Todavia, nem eles próprios, nem os santos comentadores de suas palavras escreveram em lugar nenhum que os bispos ou presbíteros foram enviados para fazer isso, mas justamente o contrário...E dado que esses malfeitores podem ser padres e leigos cometendo toda espécie de transgressões que enumeramos no capítulo II [§ 7, p. 221-222] desta Parte, resulta necessariamente que todos eles devem estar submissos ao julgamento coercivo, dos reis, duques e dos demais governantes seculares que, como o demonstramos no capítulo XV da Primeira Parte, foram investidos com a autoridade para tal mister, pelo legislador humano, pois, como diz São Pedro, Deus os enviou 'para a punição dos malfeitores e para o louvor dos que fazem o bem', visto que 'esta é a vontade de Deus', como ele o afirma igualmente no mesmo passo da Escritura'." Cf., também, doutrina semelhante em II, XXV, § § 1, 4-7, p. 553-554; 556-561. XXIX, § § 1, 3-4, p. 660-661; 662-663. XXX, § 4-5, p. 677-682. 
pouco importam o cargo ou a dignidade que possuam, na hipótese de, comprovadamente, ter sido acusado de haver cometido um delito, não interessa a sua natureza. $^{12}$

Constata-se, pois, que ao sustentar que Cristo e os Apóstolos foram submissos às autoridades seculares e que, neste mundo, não quiseram exercer qualquer espécie de poder político, bem como transmitiram esses ensinamentos e deram tal testemunho aos seus sucessores, face à sua concepção monolítica relativa à organização e ao poder estatal, ${ }^{13}$ o objetivo de Marsílio era desqualificar os ministros eclesiásticos em geral como possuidores dum poder para fazer isso, tanto na esfera espiritual, quanto, principalmente, na temporal.

Examinemos agora, no Artigo 68, o discurso alvarino, acerca da citada $1^{\text {a }}$ proposição.

À partida, frei Álvaro alega que Jesus foi julgado por Pôncio Pilatos na condição de simples homem ou pessoa particular, não como um dignitário da religião judaica, porquanto foi acusado por seus adversários de que estava a perturbar a ordem política estabelecida. Por isso, continua o Frade galego, "a raposinha manhosa, Marsílio de Pádua", sem ter a formação teológica requerida aqui e acolá, pinça frases esparsas do Novo Testamento e interpreta-as literalmente e as aplica conforme os propósitos que almeja atingir.

Para mais, na condição de vigário de Cristo na terra, estabelecido à frente da Igreja, e pessoa pública, o Papa sucede-O nos seus poderes régio e sacerdotal, de modo que, por esse motivo, ele absolutamente não está sob o foro do Imperador.

Por fim, o Menorita galego arremata suas considerações a respeito desse assunto, de um lado, invocando como provas de sua tese as opiniões de dois Padres da Igreja, Santo Ambrósio e São Jerônimo, e, de outro, reportando-se a textos do direito canônico. ${ }^{14}$

12 Ibidem, II, V, § 10, p. 270-271: “...Portanto, considerando que através da Lei Divina não foi concedido nem permitido a nenhum bispo ou presbítero exercer neste mundo o poder ou a junisdição coerciva, mas justamente o contrário,isto é, foi-lhes proibido exercê-la, mediante preceito ou conselho, como temos condição de verificar de modo claro a partir do que foi dito neste e no capítulo anterior, e considerando também que não lhes compete, enquanto tal, exercer um poder desse tipo, graças ao direito de sucessão hereditária ou paterna, disso resulta necessariamente que eles próprios devem estar submissos nesse aspecto aos juízes seculares, conforme podemos obviamente deduzir das palavras dos Apóstolos Pedro e Paulo e das explicações de outros santos... Resulta disso igualmente que nenhum bispo ou papa possui nem exerce neste mundo a jurisdição coerciva sobre ninguém, sacerdote ou leigo, salvo aquela que lhe for dada pelo legislador humano, o qual, no entanto, sempre conserva o direito de revogá-la, ocorrendo motivos razoáveis, cuja avaliação plena é da competência do mencionado legislador, especialmente nas comunidades cristãs...".

13 Cf. José Antônio de C.R de SOUZA, "A composição e a organização da sociedade civil segundo Marsílio de Pádua", in Sociedade Civil entre Miragem e Oportunidade (coord. António M. MARTINS), Faculdade de Letras, Coimbra, 2003, p. 297-317.

${ }_{14}$ Estado e Pranto da Igreja, vol. III, INIC, Lisboa, 1991, p. 337-339: “...J. Agora quanto à objecção do novel heresiarca, Marsílio de Pádua, de que Pilatos julgou Cristo e assim também o imperador pode julgar o papa, respondo que não o julgou como pessoa pública ou preeminente em dignidade, mas como pessoa privada, acusada perante ele pelos principais da sinagoga e pelo povo dos judeus como malfeitor, que, neste caso, era do foro de César e do seu, pois como governador representava o imperador na Judéia. Por isso é que o mesmo Pilatos disse (Lucas, XXIII): Apresentastes-me este homem como homem privado, não como pontífice ou constituído em dignidade, e eis que, interro- 
Como pode ser verificado, comparando a referida passagem do Artigo $68 \mathrm{com}$ o passo correspondente da Epistula, ${ }^{15}$ antes mencionada, sob os aspectos doutrinal e formal do discurso, não há diferença alguma entre ambos, exceto quanto ao pequeno acréscimo que frei Álvaro aditou ao segundo texto.

gando-o eu diante de vós, não encontro nele culpa alguma. De facto, então Cristo não tinha a pessoa de papa, mas a de um simples homem acusado perante o seu juiz. Por isso, o papa nisto não sucedeu a Cristo; sucedeu a Cristo no poder, e não na acusação maligna feita contra Deus. Eu julgo até que, se perante Pilatos fosse acusado um dos pontífices do templo, ele teria dito o que disse de Cristo: Tomai-o vós, e julgai-o segundo a vossa lei (João, XVIII). Por conseguinte, a raposinha manhosa, Marsílio de Pádua, alegou uma letra do Evangelho que o mata (2 $2^{a}$ Ep. aos Cor., III), e não o verdadeiro entendimento espiritual e até literal que oxalá o converta e vivifique. Mas também os judeus acusadores de Cristo não o acusaram a Pilatos como pontífice ou escriba, mas como um enganador do povo, dizendo por isso: Encontramos este homem sublevando a nossa gente (Lucas, XXIII). Portanto, não procede o argumento do lobo rapace, porque, se o imperador julgasse o papa, não o julgaria como um Tício ou um Semprônio ou qualquer outro particular, mas como papa. E é para isto que aquele ímpio alega este exemplo! Se aquele ignorante presumido fosse um verdadeiro sabedor das Escrituras divinas, ou se não fingisse que sabe, tomaria o sentido e inteligência das palavras do Evangelho, e não só [a letra] (Causa I, q. I, cap. Marcion).Além disso, como não se envergonha de aduzir tal exemplo, quando o próprio Pilatos confessa que julgou Cristo erradamente? Por isso é que também disse (Lucas, XXIII): Não encontro neste homem crime algum, e de novo: Eis que, interrogando-o eu diante de vós, não encontro neste homem nenhuma culpa daquelas de que 0 acusais. Nem Herodes tampouco.

Donde Ambrósio ibi: "Aqui Pilatos absolve Cristo em juízo, e crucifica-o em mistério; portanto, pelo testemunho destes dois homens Cristo é declarado inocente". E de novo em João, XIX: eu não encontro nele crime algum. Sobre isto Crisóstomo: "Pilatos não disse que Cristo pecou e era digno de morte, mas Perdoai-Lhe por ser tempo de festa; primeiro desculpou-o e depois pediu abundantemente que, se o não quisessem soltar inocente, pelo menos lhe dessem o perdão do tempo de festa". Por conseguinte, não se deve julgar por um exemplo pernicioso, como fez este herege, mas pelas leis (Código, tit. De sententia et interlocutionibus omnium iudicum, lei Nemo; veja-se a Dist. XX, cap. final)..."

${ }_{15}$ Op. cit., p. $110 \S 12$ - Na verdade, o que assevera aquele mais recente heresiarca, a saber, que Pilatos julgou Cristo, replico enfaticamente dizendo, que não O julgou como pessoa pública possuidora de dignidade elevada, mas como pessoa privada, acusada, perante ele, de ser malfeitor, pelos príncipes dos sacerdotes e pelo povo judeu, de modo que nesta circunstância, estava, pois, sob seu foro e o de César, dado que Pilatos era governador da Judéia, por ordem do Imperador. E isto quer dizer que Ele foi julgado como pessoa particular, é tão evidente,em vista de o próprio Governador ter dito: trouxestes-me esta pessoa como se fosse um malfeitor, e 'não encontro neste homem nenhum motivo de condenação' [Lc 23, 14]. Ora, Cristo, naquela circunstância, não representava a pessoa do Papa, antes, se tratava, dum simples homem, acusado perante o seu juiz, donde, em tal circunstância o Papa [110] não sucede Cristo, sucede-O, sim, no poder, não na acusação malévola de que foi vítima. Na verdade, acredito que, se um dos pontífices do templo tivesse sido conduzido perante Pilatos, ele, ao contrário, teria certamente dito o que falou a respeito de Cristo: 'Tomai-o e julgai-o segundo vossa lei' [Jo. 18, 31]. Por conseguinte, aquele paduano astucioso, vestido com pele de raposa, em favor de seu argumento, alega a literalidade do Evangelho,que ele mata, não o seu significado espiritual e verdadeiro, que, oxalá, lhe venha a dar vida e o converter.

Ora, os acusadores de Cristo também não O incriminaram perante Pilatos, como pontífice, ou profeta, ou escriba, mas como um tipo de enganador do povo, donde afirmavam: 'Encontramos este homem subvertendo o povo' [Lc 23, 2], etc. Logo, o exemplo desse lobo rapace não procede, porque, se o Imperador julgasse o Papa, não o faria como Tício ou Semprônio ou outra pessoa particular, mas como Papa. E com esse propósito, aquele ímpio aduz o mencionado exemplo. Na verdade, se aquele pretenso sábio, realmente, conhecesse a Escritura divina, ou se não dissimulasse que conhece o sentido e o significado das palavras do Evangelho, vociferando para os outros tal coisa, e se prejudicando, aceitaria, não apenas a literalidade do texto, mas também a sua interpretação mais profunda...". 
Quanto à $2^{\underline{a}}$ proposição imputada a Marsílio pelo Menorita galego, antes aludida, primeiramente, ela significa que, sob os aspectos sacramental e jurisdicional, não haveria nenhuma diferença entre os sacerdotes, os bispos e o Papa.

De fato, o Médico paduano defendia a tese segundo a qual, no tocante ao caráter ou autoridade essencial ou primária ou inseparável, inerente ao sacramento da Ordem, e esses são os conceitos utilizados por ele, tanto os sacerdotes ou presbíteros, quanto os bispos e próprio Sumo Pontífice, indistintamente o possuem, quer dizer, através daquela graça conferida imediatamente por Cristo, por intermédio da cooperação dos próprios ministros eclesiásticos, todos eles podem fazer tudo o que se enquadra no âmbito desse Sacramento. ${ }^{16}$

Todavia, Marsílio admitia haver uma diferença entre o presbítero e o bispo, a qual ele conceituava como secundária ou acidental ou separável, relativa apenas à capacidade de um deles liderar os demais, no que respeita à administração eclesiástica. Entretanto, a escolha desse líder, para desempenhar tal função, efetuada pelos clérigos de determinado lugar, portanto, algo puramente humano, não lhe acrescentava nada mais, ${ }^{17}$ digamos, sob o aspecto sacramental, à semelhança do

${ }^{16}$ Defensor da Paz II, XV, § 4, p. 410-411: "Esse caráter sacerdotal, uno ou múltiplo, que, como dissemos, é o poder de celebrar o sacramento da Eucaristia, quer dizer, de consagrar o corpo e o sangue de Cristo, e ainda o poder de ligar ou desligar os homens de seus pecados, caráter esse que de agora em diante chamaremos de autoridade essencial ou inseparável do sacerdote, parece-nos, com alguma probabilidade, ser o mesmo, sob a ótica da espécie, que está em todos os padres, de modo que o Bispo de Roma ou qualquer outro, em razão disso, pouco importa quem seja, não o possui em maior grau do que os demais sacerdotes...".

"Na verdade, Jerônimo, ao comentar a frase que se encontra no Evangelho de Mateus, capítulo XVI [19]: 'E tudo o que ligares na terra...' etc., declara o seguinte: 'O mesmo poder jurisdicional' (que Pedro detém) 'é igualmente possuído pelos outros Apóstolos, a quem, Ele' (Cristo) 'disse, após sua Ressurreição: 'Recebei o Espírito Santo, a quem perdoardes os pecados ser-lhes-ão perdoados...,etc. Toda a Igreja, através de seus sacerdotes e bispos, tem esse poder',e Jerônimo nessa passagem menciona primeiramente os sacerdotes, porque esse poder e caráter de maneira essencial pertence ao sacerdote enquanto tal.

No que concerne ao poder, para celebrar o Sacramento da Eucaristia, ninguém contesta que este seja possuído da mesma maneira, tanto por qualquer sacerdote quanto pelo Pontífice Romano.

Por esse motivo, é preciso não dar crédito à opinião de alguns indivíduos que negam isso, afirmando obstinadamente, mas sem razão, que o Papa recebeu de Cristo um poder das chaves maior do que o concedido aos outros sacerdotes, pois essa assertiva não se encontra registrada em nenhuma passagem da Escritura, aliás, é justamente o contrário.

§ 5-Para mais claramente elucidar esse ponto, não podemos ignorar que os termos "presbítero" e "bispo" eram sinônimos na Igreja Primitiva, se bem que fossem aplicados à mesma pessoa por força de atributos diferentes.

Com efeito, na Igreja Primitiva alguém era designado presbítero em razão de sua idade, isto é, pelo fato de ser um ancião. Por outro lado, o termo "bispo" era-lhe atribuído por causa de sua dignidade ou porque tinha a obrigação de cuidar dos outros fiéis, como se fosse um supervisor.

Daí, Jerônimo, em sua carta dirigida ao sacerdote Evandro, costumeiramente intitulada Sobre a diferença entre os sacerdotes e diáconos, afirmar o seguinte: 'Presbítero é um nome atribuído a alguém por causa da idade, bispo, em razão da dignidade. É por esse motivo, também, que as Epístolas a Tito e a Timóteo tratam da ordenação do bispo e do diácono, mas não fazem referência à do presbítero, porque o sacerdócio está contido no episcopado'. [S. Jerônimo, Ep.146, Ad Evangelium, PL, XXII: 1195]. Cf. também II, XVI, § § 2-4. p. 420-423.

17 Defensor da Paz II, XV, § 6, p. 413-414: "Entretanto, após a Era Apostólica, o número de presbíteros aumentou consideravelmente. Estes, com o propósito de evitar escândalos e cismas, escolheram um dentre eles para dirigi-los e guiá-los, tanto no exercício de seu encargo e ministério eclesiástico, 
que ocorre na organização eclesiástica, em decorrência dos graus hierárquicos inerentes ao próprio sacramento da Ordem.

É evidente que, ao propor essas idéias, tendo-se presente a concepção unitária do Estado defendida por Marsílio no Defensor da Paz, ele tentava desmantelar a hierarquia eclesiástica, fundamentada na teologia do Sacramento da Ordem, e em especial, a preeminência ou o primado jurisdicional do Papa na esfera espiritual, tese essa que ele reitera insistentemente em sua obra, nas quais se estribavam as pretensões do pensamento hierocrático sobre o âmbito secular.

Passemos, agora, à análise do discurso de Álvaro Pais, no Artigo 68, sobre a mencionada proposição atribuída ao Médico paduano.

Inicialmente, convém chamar a atenção para o fato de que a refutação dessa proposição se divide em três partes. Na primeira, frei Álvaro arrola os princípios teológico-canônicos relativos ao Sacramento da Ordem, quais sejam: 1 - qualquer bispo possui um poder jurisdicional ou administrativo maior do que todo sacerdote. 2 - Igualmente, todo arcediago ou arquidiácono, embora não tenha sido ordenado sacerdote ou presbítero, tanto no governo da diocese quanto no do cabido, tem um poder administrativo maior do que todo padre, inclusive do arquipresbítero ou arcipreste. 3 - Conquanto, outrora, as palavras presbítero e bispo fossem sinônimos, e o próprio São Pedro se intitulasse presbítero, mais tarde, por força dos direitos consuetudinário e escrito, bem como devido às instituições eclesiásticas, elas passaram a ter uma conotação distinta. 4 - Dado que os bispos possuem a plenitude do Sacramento da Ordem, ao passo que os padres não a têm, eles não só lhes estão subordinados hierárquica e jurisdicionalmente, mas também não podem fazer tudo o que um antístite faz, por exemplo, ordenar um presbítero, conceder-lhe o exercício do poder sacramental em sua diocese, consagrar junto com outros bispos um bispo eleito. 5 - Todos os bispos e o papa possuem a plenitude do Sacramento da Ordem; entretanto, somente o Sumo Pontífice, sucessor de Pedro, como o próprio Apóstolo, é o líder dos demais antístites, porque de Jesus

\footnotetext{
como na distribuição das ofertas e na organização mais conveniente do resto das coisas que lhes competia fazer...".

"Devido àquele novo costume que se foi generalizando, o presbitero que era eleito para dirigir os demais, passou a conservar exclusivamente para si o nome de bispo, como se fosse um superintendente, porque supervisionava não só os fiéis, motivo esse pelo qual todos os presbiteros na Igreja Primitiva eram chamados de bispos, mas também os demais co-sacerdotes...".

$\S 7-T o d a v i a$, a mencionada eleição ou escolha efetuada pelo ser humano, absolutamente não acrescenta um mérito essencial, uma autoridade ou um poder sacerdotal maior a ninguém que tenha sido indicado por seu intermédio. Propicia-lhe, sim, apenas um certo poder no tocante à organização interna da casa ou templo de Deus, quer dizer, a capacidade para instituir e dirigir os outros padres, diáconos e demais ministros, do mesmo modo que, atualmente, o superior de um mosteiro exerce uma certa autoridade sobre os monges...".

"Por esse motivo é que o Bispo de Roma não possui maior autoridade sacerdotal essencial do que qualquer outro antístite, da mesma forma como São Pedro não a teve em relação aos outros Apóstolos. Na verdade, todos receberam a mesma autoridade de Cristo, numa proporção equivalente e de modo imediato, como o demonstramos anteriormente...".
} 
recebe a plenitudo potestatis sobre toda a Igreja, enquanto bispos são vocati in partem solicitudinis, exclusivamente, para a sua diocese. ${ }^{18}$

Na segunda parte, o frade galego passa a redargüir as incongruências da citada proposição. 1 - Se os sacerdotes e os bispos, em geral, tivessem tanto poder quanto o Papa, na Igreja una deveria haver um número correspondente de vigários de Cristo sobre a Terra. Ora, consoante os ensinamentos dos Evangelhos, corroborados pelo direito canônico, foi somente a Pedro, e na pessoa dele aos seus sucessores, os Sumos Pontífices, que Jesus fundou a sua Igreja, concedeu-lhe o poder das chaves e o poder de pastorear toda sua grei. 2 - Igualmente também, de acordo com as mesmas fontes, só Jesus Cristo e seu vigário visível na Terra, o Santo Padre, é o único esposo da Igreja una, de modo que se não fosse dessa maneira, ela teria muitas cabeças, como se fosse um monstro. 3 - Os sacerdotes sucedem e representam os 72 discípulos, os quais não tinham tanto poder quanto os Apóstolos e Pedro, a quem foi confiada e partilhada a evangelização do mundo. Os sucessores deles, respectivamente, são os bispos e o papa. 4 - O sacerdócio de Melquisedeque prefigurou o sacerdócio de Jesus Cristo, enquanto o dos levitas simbolizou o sacerdócio presbiteral do Novo Testamento. 5- Por fim, de acordo com o que ensinam os cânones, na Igreja, todo poder jurisdicional exercido pelos bispos e pelos sacerdotes provém do Sumo Pontífice, considerado como a fonte única e primeira do qual eles emanam. Daí, o papa não poder compartilhar toda sua jurisdição com alguém, criando um outro papa igual a si próprio, posto que, se

18 Estado e Pranto da Igreja, vol. III, INIC, Lisboa, 1991, p. 339: "L. Em seguida, aquele enorme ímpio dogmatiza que qualquer presbítero tem tanto poder como o papa. Mas ninguém de fé sã ignora que isso é falso e errôneo, porque não só o papa mas qualquer bispo é superior em jurisdição e administração a qualquer presbítero. Com efeito, ele é pré-ordenador em todas as coisas (Dist. XXV, cap. Perlectis, vers. Ad episcopum; Decretais, tit. De officio archidiaconi, cap. II, e tit. De officio archipresbiteri, cap. Officiun, no fim). E até não só o bispo é maior em jurisdição que o presbítero, mas mesmo o arcediago, que é diácono também, é superior em administração, não só a qualquer presbítero, mas mesmo ao arcipreste, não obstante este ser-lhe superior na ordem (como vem no préalegado cap. Perlectis, e nas Decretais, De officio archidiaconi, cap. Ad haec, § Archipresbyteri). De facto, pode um ser maior na administração, embora seja menor na ordem (como se nota na Dist. XXI, cap.ln nouo, na glosa Ar.). Item, embora outrora o mesmo se dissesse presbítero e bispo (como vem na Dist. XCIII. cap. Legimus), e o Papa Pedro se chame presbítero (ibi, vers. Sed et Petrus e na glosa Ecce Petrus), todavia, pelo costume, pelo direito e pelas ordenações foi determinado que os presbíteros se submetam aos bispos e estes sejam maiores que eles, não só na ordenação e consagração episcopal (como vem no mencionado cap. Legimus, verso Quid enim), mas também na administração, no nome, na jurisdição e quanto a certos sacramentos apropriados aos bispos (Dist. XCV, cap. Olim e cap. Ecce; também sobre isto anotei plenamente ao predito cap. Legimus, na glosa Hic respondet).

Ora, o Sumo Pontífice não só é maior em tudo que qualquer presbítero, mas é também maior que todos os bispos, excepto na consagração episcopal. Na verdade, a Pedro também foi dado pelo Senhor o poder sobre os outros apóstolos de quem os bispos são sucessores (Dist. LXVIII, cap. Quorun uices, onde se resolve esta matéria; Dist. XXI, cap. In nouo, que convém ver; Dist. LXXX, cap. In illis, que convém ver; e se nota na Causa XXIV, q. I, cap. Loquitur, e na Causa II, q. VII, cap. Paulus, na glosa I, e cap. Quamquam, onde diz «embora o episcopado seja maior que o presbiterado»; também faz o que aí se anota na glosa Augustini hoc)...". 
isso viesse a ocorrer haveria uma quebra da auctoritas una que ele possui e exerce. $^{19}$

Esse último argumento, bem como aquele outro relativo ao governo uno da Igreja una, merecem uma atenção especial, dada a concepção filosófica que o sustenta. Fundamentam-se eles no neoplatonismo cristianizado de Dionísio Areopagita, (c. séculos VI-VII), cujos principais escritos de cunho filosófico-teológico são o De caelesti hierarquia e o De ecclesiastica hierarquia ${ }^{20}$ e, certamente, Frei Álvaro recolheu-os no tratado Sobre o poder eclesiástico ${ }^{21}$ de Egídio Romano OSA (c. 1247-1316) e na bula Unam Sanctam ${ }^{22}$ de Bonifácio VIII (1294-1303), de 18 de novembro de 1302, em que se encontram explicitados.

De acordo com tal pensamento, há uma organização hierárquica entre todos os seres do universo, regidos pela lex divinitatis, de tal modo que as realidades inferiores, conforme o locus e o grau hierárquico em que se situam, são igualmente «mais materiais» do que as superiores. Ao Uno, que está no vértice dessa hierarquia, corresponde o grau de espiritualidade e imaterialidade mais excelso e dele

19 Estado e Pranto da Igreja, vol. III, INIC, Lisboa, 1991, p. 339-341: "Além disso, se os presbíteros e os bispos tivessem tanto poder como o papa, haveria no mundo tantos vigários gerais de Deus quantos os presbíteros e bispos, o que é falso e herético, pois o Senhor só a Pedro disse (Mateus, XVI) eu digo-te: tu és Pedro e depois dar-te-ei as chaves, falando no singular, e depois, falando em sentido geral, mas só para Pedro: tudo o que ligares (Decretais, De maioritate et oboedientia, cap. Solitae, § Nos autem) e ainda: Apascenta as minhas ovelhas (João, últ.; Decretais, 'De electione, cap. Significasti).

Por outro lado, segundo este erro de Marsílio a Igreja una teria muitas cabeças como um monstro (Decretais, De officio ordinarii, cap. Quoniam), e seriam muitos os esposos da Igreja universal, o que é falso, porque só um, Cristo, desposou a Igreja una, e um só, o seu vigário geral, é esposo da Igreja. 2a aos Cor., XI: Desposei-vos para vos apresentar, como virgem casta, a um único esposo, Cristo (Causa XXVII, q. I, cap. Nuptiarum). E aquilo do apóstolo (Ep. aos Efésios, V), explicando as palavras do primeiro homem Eis aqui agora o osso dos meus ossos, etc...: "Mas eu digo que este mistério é grande em relação a Cristo à Igreja" (Decretais, De bigamis, cap. Debitum; faz a Dist. XXVI, cap. II).

Item, os presbíteros têm o tipo dos 72 discípulos (Dist. XXI, cap. In nouo; Dist. LXVIII, cap. Corepiscopi), mas o papa o de Cristo; ora, aqueles 72 discípulos não tiveram tanto poder como os apóstolos, que sozinhos partilharam o mundo para pregar e converter, e muito menos que Pedro e Paulo.

Item, só Melquisedeque teve o tipo de Cristo. Por isso, vem nos Salmos, CIX: "Tu és sacerdote para sempre, etc...". Os outros presbiteros do Velho Testamento têm o tipo dos outros sacerdotes do Novo Testamento (Dist. XXI, § 1); por isso, lê-se nas Decretais, De constitutionibus, cap. translato: "Transferido o sacerdócio, etc...".

Item, como toda a jurisdição, quer dos bispos, quer dos presbíteros desce do papa como primeira fonte (Dist. XXII, cap. I, Causa XXIV, q. I, cap. Loquitur), não pode o papa dar a outro toda a sua jurisdição por forma que esse outro tenha tanta como ele mesmo; doutro modo, poderia fazer um arquipapa ou pelo menos um outro papa igual a si, o que é falso (Causa VIII, q. I, cap. Si Petrus com os cap. seg.), pois nem pode fazer outro papa nem privar-se da sua jurisdição. Para isto faz o que se lê e nota nas Decretais, De censibus capo Cum uenerabilis, na glosa Hic patet, e nas Decretais, De donationibus cap. Pastoralis, na glosa Si ita...".

20 Esses textos encontram-se no vol. 3 da $P G$. O monge João Escoto Eriúgena (c. 810-877), que ensinou na escola palatina de Carlos o Calvo (823-877) traduziu-as do grego para o latim.

${ }^{21}$ Cf. a tradução em vernáculo desta obra por Luís Alberto DE BONI e Cléa GOLDMAN. Petrópolis: Vozes, 1989.

${ }^{22}$ Cf. José Antônio de C. R. de SOUZA e João Morais BARBOSA, O reino de Deus e o reino dos homens, As relações entre os poderes espiritual e temporal na Baixa Idade Média (da Reforma Gregoriana a João Quidort), Porto Alegre, EDIPUCRS, 1997, documento 50, p. 203. 
emanam as realidades superiores; as outras delas provêm e a elas devem reduzirse pela conversão da multiplicidade à unidade e da materialidade à espiritualidade. Assim, cada hierarquia précontém em si, num grau superior, as hierarquias inferiores que, ao se lhe reduzirem, por ela são reconduzidas à outra hierarquia superior na ordem da unidade e da espiritualidade e, mediante esse processo de conversão, as hierarquias intermédias reduzir-se-ão à hierarquia suprema.

No caso do governo da Igreja (Cristandade), que se efetiva através de seus hierarcas, termo esse que o Areopagita emprega para designar os dignitários eclesiásticos, cujo étimo provém da palavra grega iereus, que significa sacerdote, os seres humanos recebem a lei de Cristo, esclarecedora e aperfeiçoadora da lex divinitatis. Do supremo hierarca, o papa, e por ser o supremo é único, cujo poder governativo recebe-o diretamente de Jesus Cristo, em seguida à sua eleição, provém todo poder jurisdicional que os hierarcas subalternos e os inferiores possuem para exercer o seu ministério sacramental, até um dado limite determinado por suas respectivas esferas ou graus de atuação.

Na terceira e última parte de seu arrazoado, com base no direito canônico e no Código do Imperador Justiniano (527-565), referindo-se à organização eclesiástica que, propositadamente, Marsílio parece ignorar, Álvaro Pais explica, de um lado, que a precedência na Igreja é devida a quatro motivos: (1) ao tempo ou à anterioridade que alguém exerce determinado cargo, por exemplo, o decano do Sacro Colégio de Cardeais; (2) às competências inerentes a este ou àquele cargo que derivam do grau sacramental relacionado com o mesmo, de modo que o sacerdote pode mais do que um simples diácono ou subdiácono, etc.; (3) à plenitude do Sacramento da Ordem, de acordo com a qual todos os bispos são iguais; (4) à superioridade própria de tal ou tal cargo, conforme a qual o arcediago era mais importante do que o arquipresbítero, embora este preceda àquele, sob o aspecto sacramental.

A par disso, ao se comparar os clérigos entre si, também pode haver superioridade ou preeminência de uns sobre os outros, decorrente de várias circunstâncias, as quais, igualmente, é preciso distinguir, a saber, (a) em razão do cargo que desempenham; (b) devido às qualidades pessoais; (c) por força das ordens maiores ou menores que possuem; (d) face à competência administrativa que exercem; (e) devido à plenitude do sacerdócio, possuída por todos os bispos.

O ápice da referida preeminência, decorrente da plenitude do sacerdócio contida no Sacramento da Ordem, reside e se resume em três competências principais, exclusivamente da alçada dos bispos e do Pontífice Romano: julgar, legislar e ministrar todos os Sacramentos. ${ }^{23}$

23 Estado e Pranto da Igreja, vol. III, INIC, Lisboa, 1991, p. 341-343: “...M. Para esclarecimento do que acabamos de expor, convém saber que na Igreja de Deus há quatro superioridades. Acrescente-se aqui o que escrevi acima no art. XXXVII, verso Primeiro e verso Há, porém.

A primeira vem do tempo (Dist. XVII, \& Hoc quoque e § Verum; Dist. XCVI, cap. Bene quidem, Dist. LXXV, cap. VItra; Decretais, De maioritate et oboedientia, cap. 1).

A segunda, da prerrogativa da Ordem (Decretais, De maioritate et oboedientia, capo Statuimus). 
Igualmente, na referida Epistula ad quosdam cardinales, há um trecho em que Frei Álvaro também refuta a aludida proposição. ${ }^{24}$

A terceira, da prerrogativa do ordenante ou constituinte (Decretais, De maioritate et oboedientia, cap. Per tuas; Digesto, De albo scribendo, lei últ.; na Autêntica Vt iudices sine quoquo suffragio, § EOS, cerca do fim, Colação II; Digesto, tit. De re iudicata, lei Quidam).

A quarta, em razão da dignidade ou superioridade do ofício. Por esta razão o arcediago diz-se maior que o arcipreste, conforme se disse, e um pode ser menor e maior que outro (Causa II, q. VII, cap. Quanquam e cap. Quaeritur). O mesmo se verifica no abade constituído em ordens menores (Decretais, De aetate et qualitate, cap. Tuam), assim como no subdiácono eleito e confirmado (Decretais, De electione, capo Transmissam).

Item, pode-se (sic) ser maior e igual, como foi Pedro maior que os apóstolos em dignidade ou ofício, mas par e igual no apostolado ou Ordem episcopal (Causa II, q. VII, cap. Puto; Dist. XXI,

Ora, naquilo em que alguém é menor deve prestar reverência a outro maior. Logo, sendo o arcediago na missa menor que o arcipreste, deve então servi-lo, mas, fora da missa, é maior que ele na palavra, no lugar, na jurisdicão e noutras coisas que lhe competem, em razão da dignidade. De acordo com isto entenda-se a Causa XXXIII, q. V, cap. Est ordo, Dist. XCIII, cap. A subdiacono, Decretais, De officio archidiaconi, cap. I. Entenda-se assim a Dist. XXI, § In his omnibus com os capítulos seguintes.

$N$. Item, cumpre notar que uma pessoa é superior a outra de cinco modos, a saber: pelo ofício (Dist. XXI, cap. In nouo); por mérito de vida (Causa II, q. VII, cap. I); pela ordem (Dist. XCIII, cap. A subdiacono); pela administração, como o arcipreste (Decretais, De officio archipresbyteri, cap. 1); e pela consagração, como o bispo que por ela é superior a todos (Dist. XXI, cap. I).

O. Esta prelazia (superioridade) consiste em três coisas: nos juízos (Dist. XXI, cap. Inferior), nos preceitos (Dist. XXI, cap. Nunc autem), e nos sacramentos (Dist. XXI, cap. Denique), segundo o Arcediago que assim anota na Dist. XXI, ao predito $\S$ In his.

Item, é de notar que o poder maior considera-se umas vezes resultante da dignidade da Ordem, e outras vezes da dignidade da governação ou administração. Ora, Pedro possuía-o, não pela prerrogativa da Ordem ou consagração, mas em razão da administração, segundo Lourenço que assim anota ao predito cap. In nouo.

Item, dizendo-se que qualquer presbítero é igual ao papa na jurisdição, confunde-se a ordem superior, contra os cânones (Dist. LXXXIX, cap. Ad hoc). Isto se deve acrescentar ao que eu sobre esta matéria disse acima no princípio desta obra...".

${ }_{24}$ Op. cit. p. 110-111 § 13. "Na verdade, o que aquele ímpio igualmente dogmatiza, a saber, que qualquer presbítero possui tanto poder quanto o Papa, é uma mentira e um sacrilégio, dado que todo o direito declara o contrário, não apenas sobre o Papa, mas, ainda, a respeito de qualquer bispo, que está acima de qualquer presbitero, no que concerne à jurisdição e à administração".

"Com efeito, posto que Cristo conferiu os poderes de ligar e de absolver a todos os Apóstolos, os quais representam os bispos, entretanto, além disso, atribuiu só a Pedro algo mais, dizendo-lhe: 'Eu te digo que tu és Pedro', e de novo, singular e amplamente 'Dar-te-ei as chaves do reino dos céus', [Mt 16, 18-19] e novamente: 'Apascenta as minhas ovelhas'. [Jo 21, 17]

Ademais, se os bispos e os presbíteros possuíssem tanto poder quanto o Papa, todos eles, enquanto tal, seriam vigários de Cristo neste mundo, o que é uma inverdade, porque ele disse a Pedro, e não aos outros Apóstolos: 'Sobre esta pedra edificarei a minha Igreja', [Mt 16, 18] e aquilo que foi dito acima: 'Apascenta as minhas ovelhas'.

Além disso, conforme aquela opinião, o corpo uno da Igreja teria muitas cabeças, como se fosse um monstro. [111] Item, muitos seriam os esposos da Igreja universal, o que é evidentemente falso, porque foi o Cristo uno que a desposou: 'Desposei-vos a um esposo único, a Cristo, a quem devo apresentar-vos como virgem pura'. [2 ${ }^{\underline{a}}$ Cor. 11, 2] Segundo Agostinho, o Apóstolo está a falar acerca da Igreja universal, a quem chama virgem, embora lhe esteja ligado pelo matrimônio, mas há castidade no matrimônio, se o leito é imaculado. Daí, o Apóstolo dizer, [se referindo a um passo do Gênesis 2, 23]: 'Este sim é o osso', etc. 'Refiro-me à relação que há entre Cristo e a sua Igreja' [Ef 5, 32].

Logo, há uma Igreja e um só esposo, designando aquela santa união da natureza divina com a humana ocorrida no útero virginal.

Ademais os presbíteros são representados pelos setenta e dois discípulos, o Papa por Cristo. Ora, aqueles, dado que apenas foram enviados ao mundo para pregar e converter, não possuíram tanto poder quanto os Apóstolos, muito menos, quanto Pedro e Paulo. 
Comparando os dois textos, nota-se imediatamente que, no Artigo 68, Álvaro Pais amplia e esclarece suas idéias, reforçando sua argumentação, o que não significa que no mesmo haja uma evolução ou ampliação doutrinal.

Quanto à $3^{\underline{a}}$ tese imputada pelo Menorita galego ao Médico paduano, ela não se encontra em nenhum trecho do Defensor da Paz, conquanto se deva mencionar que, sob inspiração e em presença de Marsílio, isso ocorreu em Roma, em janeiro de 1328, quando, apoiado pelos eclesiásticos que lhe tinham aderido, Ludovico IV depôs o Papa João XXII, sob a acusação de que tinha sustentado uma grave heresia, qual seja, negara a absoluta pobreza de Jesus Cristo e dos Apóstolos, e, em seguida, ordenou-lhes eleger um novo papa, cuja escolha recaiu sob um de seus próprios partidários, o franciscano de Pedro de Corvara, o qual tomou o nome de Nicolau V.

Resumindo as idéias marsilianas relacionadas com essa tese, é oportuno frisar que, inicialmente, num trecho de sua obra, o Paduano diz que, embora, tanto a indicação de pessoas para integrar esta ou aquela corporação ou ofício social necessário à comunidade, quanto a coordenação do mesmo, sejam atribuições exclusivas da alçada do legislador humano e do Príncipe, por delegação daquele, no caso do líder da Igreja, tal designação, no entanto, poderá vir a ser feita por eles, desde que isso passe a constar da lei e que, sempre, se ouça a opinião dos clérigos e de outras pessoas idôneas.

No entanto, em seguida, Marsílio recorda o célebre Privilegium Otonis, obtido pelo Imperador Otão I (936-966) em 962, segundo o qual o Imperador poderia vir a designar os Papas e os prelados alemães, considerando tal privilégio um instrumento perfeitamente legal e legítimo, o qual, no seu entender, depois, veio a ser indevidamente revogado pelos Pontífices Romanos, e que, portanto, podia vir a ser restabelecido pelo legislador humano, dado que tem competência para tanto ${ }^{25}$.

Item, apenas Melquisedeque simbolizou Cristo, daí Davi afirmar: 'Tu és sacerdote para sempre'; [Ps 109, 4] os outros presbíteros do Antigo Testamento, os demais sacerdotes do Novo Testamento, por isso, está escrito: 'Mudado o sacerdócio' [Hb 7, 12] etc.

Além disso, como toda a jurisdição dos bispos e dos presbiteros procede do Papa, como se fosse a fonte primeira de onde ela emana, apesar disso, ele não pode dar toda a sua jurisdição a outrem, a ponto de essa pessoa vir a tê-la na mesma proporção que ele próprio, transformando-a num arquipapa, ou talvez, num consorte, dado que se trata duma inverdade, porque o Papa não pode instituir um outro Papa nem abrir mão de sua jurisdição".

25 Defensor da Paz II, XXV, § 8, p.561: "Na verdade, embora por força dos direitos divino e humano, ou graças a um costume louvável, não seja da competência de nenhum Príncipe e tampouco de nenhuma pessoa particular,enquanto tal, obedecendo apenas a seu impulso, a autoridade para estabelecer determinada ofício ou designar alguém para exercê-lo, especialmente para o bispado romano, conforme suficientemente o demonstramos no capítulo XV [§ 8, p. 158] da Primeira Parte, e nos capítulos XVII [§ 7, p. 445-446] e XXII [§ § 9-11, p. 513-515] desta, no entanto, pode licitamente convir ao príncipe, mediante delegação de competência do legislador humano,o direito de designar o Romano Pontífice, conforme um determinado modo e procedimento fixados pela lei, por exemplo, solicitando a opinião do grupo clerical e dando crédito à sua parte preponderante e igualmente ouvindo outras pessoas sábias e virtuosas...".

[562] § 9 - "Mas como o dissemos antes, o costume pelo qual os pastores da Igreja de Roma eram indicados pelo Imperador da maneira que nos referimos, não era pernicioso nem desonesto. De fato...lemos que a autoridade para fazer tais nomeações através do procedimento mais completo, sobre o qual aludimos precedentemente tinha sido garantido e concedido por todo o povo de Roma, 
Examinemos a réplica de Frei Álvaro a essa 3ª proposição. Primeiramente, ele a considera inusitada, tanto à luz do direito quanto da razão, afirmando, com base na teoria política hierocrata, no tocante à renovatio imperii, que não somente é o contrário que acontece, mas também que, na vacância do Império, a jurisdição imperial retornava à Sé Apostólica, porquanto esta era a sua causa eficiente.

O frade Galego também contesta aquela assertiva, reiterando novamente que o Imperador é desqualificado para tal sucessão, porque não recebeu o Sacramento da Ordem, nem tampouco a mais ínfima parcela da autoridade espiritual, mediante a qual, por exemplo, todos os sacerdotes podem, em nome de Deus, condenar ou absolver os fiéis, por causa dos pecados que cometeram, não sendo, por conseguinte, o Imperador o legítimo esposo da Igreja e vigário de Cristo na Terra, conquanto saibamos que, em princípio, qualquer cristão possa vir a ser eleito Papa, desde que venha a receber o predito Sacramento, em sua plenitude, isto é, a sagração episcopal. Todavia, a prática consagrada pelo Direito Canônico e pela Sé Apostólica, há muito tempo, estabelecera normas precisas quanto à sucessão pontifícia, tendo sido confiada ao Colégio Cardinalício, aliás, como tivemos ocasião de ver acontecer de novo, entre 02 e 19 de abril, deste ano, após o falecimento de João Paulo II (1978-2005) e a escolha de Bento XVI.

O Menorita galego ainda refuta os defensores daquela opinião, arrolando uma série de provas históricas acerca de potentados seculares que, outrora, pelo fato de terem indevidamente tentado se apossar dos bens temporais destinados à manutenção do culto divino, muito menos importantes do que a própria Sé Romana, foram severamente punidos por Deus, insinuando, com isso, que tais exemplos serviam de advertência para quem ousasse cometer essa espécie de abuso.

Por fim, com base em citações dos Padres da Igreja, inseridas no direito canônico, Álvaro igualmente afirma e ressalta que as esferas de atuação do papa e do imperador são distintas. ${ }^{26}$

clero, bispos e leigos a Carlos Magno e a Otão I, Rei dos Teutônicos, e, mais tarde, Imperador dos romanos. Por esse motivo, lemos nessas histórias autênticas, - e isso é verdade - que o edito abaixo transcrito emanou do consenso do povo romano: 'Leão, papa, ao Sínodo reunido em Roma, na igreja de São Salvador, à semelhança de Santo Adriano, Bispo da Sé Apostólica, que concedeu ao Senhor Carlos Magno, grande vitorioso rei dos Francos e dos Lombardos, a dignidade de Patriarca e os direitos de colocar em ordem a Sé Apostólica e de investir alguém na mesma.

E também nós, Leão, bispo, servo dos servos de Cristo, estabelecemos, confirmamos e corroboramos juntamente com o clero e o povo reunidos, em virtude de nossa autoridade apostólica, concedemos e outorgamos para sempre, ao Senhor Otão I, rei dos Teutônicos, e a seus sucessores, no reino da Itália, o poder, tanto para escolher seus próprios herdeiros, como para indicar o Pontífice para a suprema Sé Apostólica, e, em conseqüência, designar igualmente os arcebispos e bispos'...". [Ivo de Chartres, Panormia, VIII, cap.135 e 136, PL 161: 1129]. "Destarte, é igualmente da competência do Príncipe e do povo romano escolherem o Pontífice da Sé Apostólica, como o mostramos no capítulo XVII [§ 11, p. 449-451] desta Parte. O clero daquela cidade não está excluído do povo, ao contrário, se constituí numa parte integrante do mesmo...Por isso, não podia legalmente ter-lhe sido retirada, através duma lei ou decretal sancionada por um Bispo de Roma qualquer, sem um decreto do povo acerca da aludida atéria...". Cf. Ibidem II, XVII, § § 9-12, p. 447-452.

26 Estado e Pranto da Igreja, vol. III, INIC, Lisboa, 1991, p. 345-347: “... P. Diz também aquele pérfido Marsílio que, vagando o papado, sucede o imperador. Mas não sei donde tirou isto e como o disse, visto que toda a Escritura, como também toda a razão, contradiz esta afirmação. Na verdade, o pa- 
Cotejando essa passagem do Artigo 68 com o trecho da Epistula ad quosdam cardinales, em que Álvaro trata do mesmo assunto, ${ }^{27}$ nota-se que, salvo o acréscimo que fez ao final do primeiro deles, ambos são quase idênticos, bem como não houve, por conseguinte, uma evolução ou ampliação doutrinal.

pa sucede no império (Decretais, De foro competenti, cap. Licet; Clementinas, De re iudicata, cap. Pastoralis), e não o imperador no papado. De facto, que comunicação há entre um cão e um santo? (Eclesiástico, XIII, 2 ${ }^{\underline{a}}$ aos Cor., VI). Entre as coisas profanas e as divinas? (Decretais, De iudaeis, cap. Ad haec, Causa XII, q. II, capo Nulli). Entre o súbdito e o senhor? (Decretais, De electione, cap. Venerabilem). Como pode o imperador suceder nas coisas eclesiásticas, se é inábil para as possuir e tratar, e se até o estatuto por ele feito em favor da Igreja não vale, se não for expressamente aprovado por ela? (Dist. XCVI, cap. Bene quidem; Decretais, De Constitutionibus, cap. ECclesia). Porque Baltasar contaminou os vasos do templo, foi por Deus ferido de morte (Daniel, V; De consecratione, Dist. I, cap. Vestimenta). Item, Ozias, rei de Judá, porque quis usurpar as funções dos sacerdotes, foi pelo Senhor ferido de lepra ( $2^{\circ}$ dos Paralipómenos, XXVI; Causa II, q. VII, cap. Item cum Balaam, verso Sicut ergo). Item, Heliodoro, enviado pelo rei Antíoco a invadir o erário do templo onde estavam os depósitos de dinheiro, foi ferido pelas patadas dum cavalo, que miraculosamente apareceu, e deixado semivivo ( $2^{\circ}$ dos Macabeus, III).

Item, se o imperador sucedesse no papado, então desligaria e ligaria, mas as chaves foram dadas por Deus, não aos imperadores, mas a pescadores (De poenitentia, Dist. I, cap. Quem poenitet), e não aos leigos, mas aos presbíteros. Efectivamente, o imperador é anatematizado e religado pelos sacerdotes da Igreja (Dist. XCVI, cap. Duo; para isto fazem a Dist. XCVI, cap. Satis euidenter, e a Dist. XVII, § Hinc etiam).

Item, Ambrósio diz ao imperador que queria ocupar uma igreja: "Que há entre ti e a adúltera? Adúltera é a que não está ligada a ti por legítimo matrimônio. Pertença o palácio ao imperador, e a igreja ao antístite" (Causa XXIII, q. VIII, cap. Conuenior). Ora, neste aspecto, são distintos os ofícios dos pontífices e os dos imperadores romanos (Dist. X, cap. Quoniam, e Dist. XCVI, cap. Cum ad uerum). Por isso, se diz, no fim deste último cap., acerca do imperador: "e, por seu turno, não se visse presidir às coisas divinas aquele que estivesse implicado nos negócios seculares". Veja-se acima o art. XL, vers. Item, é erro..

${ }_{27}$ Op. cit., § 14, p. 111: "O que também assevera aquele ímpio paduano, a saber, que, vago o Papado, o imperador sucede [o papa morto], ignoro onde encontrou essa falsa proposição, ainda mais que ela é contrária ao que estabelece todo o direito e à razão. Na verdade, o Papa bem o sucede, vago o Império, não o contrário. De fato, que relação há entre um cão e um santo, as coisas divinas e as profanas, a carne e o espírito, entre o senhor e o súdito? De que modo o Imperador pode sucedê-lo na esfera espiritual, uma vez que é incompetente para ocupar-se e para tratar dela. [112] Com efeito, ainda que ele promulgasse um estatuto relativo a questões eclesiásticas, e que fosse proveitoso à Igreja, tal estatuto seria nulo, a menos que o Papa o confirmasse, a fim de que se respeite o que é estipulado pelo direito. Com efeito, da parte do Imperador, no tocante à esfera eclesiástica, o dever de obsequiar é permanente, não a necessidade de mandar.

Item, se César sucedesse o Papa no Papado, ele próprio seria o esposo da Igreja, afirmação essa, que, não apenas é uma impiedade, mas também uma insensatez. Na verdade, Ozias, tendo tocado as coisas sagradas, foi castigado com a lepra, Baltasar tendo profanado os vasos sagrados, ouviu as palavras Mane, Tecel, Fares e foi privado de sua vida e de seu reino. Daí, Ambrósio ter dito ao Imperador que queria ocupar a igreja :'O que há entre ti e a adultera? É adultera porque não está casada contigo, através dum matrimônio legítimo. O palácio pertence ao Imperador, a igreja ao bispo'. [Ep. XX Ad Marcellinam sororem, PL XVI: 1042]. Heliodoro, querendo se apoderar do tesouro depositado no templo, foi miraculosamente ferido com as patas dum cavalo, e foi deixado semivivo. Antíoco, violador das coisas sagradas, teve de ser transportado numa padiola, e terminou os seus dias apodrecendo com um fedor intolerável que se espalhava por todo o acampamento.

Semelhantemente, se o Imperador sucedesse o Papa no Papado, então absolveria e ligaria, mas as chaves foram dadas por Deus aos pescadores, não aos imperadores, não aos leigos, mas aos presbíteros. Na verdade, é o Imperador que é anatematizado e ligado pelos sacerdotes da Igreja, não o contrário...". 
A $4^{\text {a }}$ das proposições imputadas ao Paduano pelo frade Galego, conforme vimos antes, se refere ao fato de a Igreja e os clérigos em geral não terem o direito de possuir bens.

Marsílio discorreu amplamente sobre esse assunto em vários capítulos da $2^{\underline{a}}$ Parte do Defensor da Paz, ${ }^{28}$ tendo elaborado a respeito do mesmo uma teoria relativamente original $^{29}$ (embora nela se possa vislumbrar a experiência da heresia albigense ou cátara, ${ }^{30}$ misturada com os anseios dos Espirituais Franciscanos ${ }^{31}$ ), com dois propósitos: de um lado, refutar bula Cum inter nonnullos (novembro de 1323) de João XXII, comprovando a heresia do citado Papa, e de outro, tornar o clero completamente pobre e dependente do Estado.

Os pontos mais relevantes dessa teoria podem ser resumidos nos seguintes: (a) Cristo e os Apóstolos praticaram a mais estrita e excelsa pobreza e a ensinaram e aconselharam que todos os seus seguidores a praticassem, como o caminho para alcançar a perfeição. ${ }^{32}$ (b) Os presbíteros ou bispos, o Papa e o clero em geral, na condição de discípulos de Cristo e dos Apóstolos, dado que se dizem seus imitadores e almejam igualmente atingir a perfeição evangélica, devem praticar tal tipo de pobreza, não podendo possuir nenhum tipo de propriedade sobre qualquer

Defensor da Paz, II, capítulos XI-XIV, p. 330-406

${ }^{29}$ Cf. José Antônio de C.R. de SOUZA, "As Teses do Defensor Pacis II, XIII", Revista da Faculdade de Ciências Humanas e Sociais da Universidade Nova Lisboa, vol. 7 (1994): 205-227. (Atas do Colóquio As Relações de Poder no Pensamento Político da Baixa Idade Média).

30 Cf. José Antônio de C.R. de SOUZA, "O Catarismo: movimento religioso heterodoxo popular urbano", in Fragmentos de Cultura, UCG, Goiânia, vol. 11 (2001): 341-354.

31 Cf. N. FALBEL, Os Espirituais Franciscanos, S.Paulo, EDUSP/PERSPECTIVA/FAPESP, 1995. M. DAMIATA OFM, Guglielmo d'Ockham: Povertà e Potere, vol. I, Firenze, Edizioni Studi Francescani, 1978.

32 Defensor da Paz II, XI, § 2, p. 331-332: “Jesus nasceu pobre e, quando cresceu, também viveu na pobreza. Daí, falando a respeito de sua pobreza, nos Evangelhos de Mateus, capítulo VIII [20] e de Lucas, capítulo IX [58] , declara o seguinte: 'As raposas têm tocas e as aves do céu ninhos, mas o Filho do Homem não tem onde reclinar a sua cabeça'.

Cristo, considerando que esse estado era o da perfeição, recomendou que optassem pelo mesmo, a todas as pessoas que, tendo devidamente observado os outros conselhos e mandamentos, quisessem ser os seus principais discípulos e imitadores, particularmente seus sucessores no ofício em que ele tinha vindo ao mundo para exercer.

$\S 3$, p. 332: "Nota-se, pois, que o estado de pobreza e de desapego pelo mundo convém a todo homem perfeito, especialmente ao discípulo e sucessor de Cristo no ministério pastoral, mais ainda, é praticamente indispensável à pessoa que deve persuadir os outros acerca do desapego pelo mundo, se quiser ser bem sucedido em seu ensinamento ou pregação. Com efeito, se ela possuir riqueza e aspirar ao poder, ensinando aos outros desprezá-los, seus atos contradirão explicitamente às suas palavras...".

Defensor da Paz, II, XIII, § 36, p. 376: "Cristo foi a pessoa, dentre os peregrinos neste mundo, que observou todos os preceitos da maneira mais perfeita. Portanto, o Filho do Homem não teve nem desejou ter aquela espécie de propriedade sobre os bens materiais, que a Escritura designa freqüentemente por possessão, conforme se lê no Evangelho de Lucas, capítulo XIV [33]: 'Aquele que não renunciar a tudo o que possui...', da mesma forma lê-se também no Evangelho de Mateus, capítulo $X$ [9]: 'Não leveis ouro, nem prata, nem moeda nos vossos cintos', isto é, não os conserveis, salvo talvez por um motivo justo e com a intenção de suprir as necessidades sobre as quais nos referimos anteriormente, v. g., como o caso dos pobres sem recursos...". 
bem material. ${ }^{33}$ (c) Os bens materiais oferecidos à Igreja pelos senhores temporais ou por particulares, os quais mantêm o direito de propriedade sobre os mesmos, se destinam exclusivamente ao sustento do clero e dos carentes. ${ }^{34}$ (d) Se o clero, em geral, e a Igreja quiserem continuar a possuir tais bens, não podem, por conseguinte, considerar-se verdadeiros seguidores de Cristo e praticantes da mais excelsa pobreza. ${ }^{35}$

Vejamos como Álvaro Pais redargüiu a essa $4^{a}$ proposição, no Artigo 68. Para começar, ele afirma que tanto os leigos quanto os clérigos, estes não de condição inferior àqueles, sob o amparo de ambos os direitos, legitimamente, podem possuir bens materiais e ter dinheiro.

Em seguida, em primeiro lugar, afirma que essa opinião herética não é nova (tenhamos presentes, por exemplo, os Valdenses), porque outros já a defenderam, inclusive ao terem afirmado que, desde o tempo de Constantino I (313-337) e de Silvestre (314-335), a Igreja traiu os ensinamentos de Jesus, tendo aceito as doações territoriais e outros bens valiosos que o citado imperador fizera ao referido papa.

Depois, remetendo o leitor aos capítulos 4 [32, 34-35] e 5 (sic) dos Atos dos Apóstolos, sem transcrever as passagens, frei Álvaro refuta a mencionada proposição, dizendo que a Igreja Apostólica possuiu dinheiro em comum, proveniente dos bens que os fiéis tinham vendido, cuja receita foi doada aos Apóstolos, com vista a prover as necessidades materiais deles próprios e de todos os membros daquela comunidade cristã. Um pouco mais adiante, com base no que testemunham a História e a tradição, ele acrescenta que, tendo sempre esse propósito, os prelados da Igreja Primitiva, com o dinheiro que as comunidades eclesiais possuíam, resol-

${ }^{33}$ Defensor da Paz, II, XIII, § 36, p. 376: “...No entanto, a um pobre por opção não é permitido possuir a aludida propriedade, mesmo tratando-se das hipóteses antes citadas, pois a mesma sem dúvida alguma elimina a observância do preceito de Cristo, relativa à mui excelsa pobreza, conforme sua definição específica. Portanto, ele não possuiu propriedade, conforme a acepção mencionada, sobre os bens materiais, e nenhum dos seus imitadores, isto é, a pessoa que deseja observar a regra concernente à mui excelsa pobreza não pode possuí-la...".

Defensor da Paz, II, XIV, § 6, p. 385: "[...] observando o ensinamento de Cristo e dos Apóstolos...afirmamos que os ministros do Evangelho, os bispos ou presbíteros, e ao mesmo tempo os demais clérigos, não importam sua dignidade ou posição, devem se contentar apenas com o sustento quotidiano e com as roupas necessárias, se quiserem manter o estado de perfeição ou a mui excelsa pobreza. Daí, estar escrito na 1a Epístola a Timóteo, último capítulo [VI,8]:'Se temos, pois, alimento e vestuário, contentemo-nos com isso'...Mas nenhum dos fiéis tem a obrigação de doar aos pregadores do Evangelho, parte alguma de seus rendimentos, seja o dizimo ou outra qualquer...".

34 Defensor da Paz, II, XIV, § 8, p. 387: “[...] respondemos afirmando que a propriedade sobre os bens temporais, postos à disposição dos ministros do Evangelho para o seu sustento, pertence ao legislador ou.. aos que os ofertaram, tratando-se de particulares, os quais, tendo feito um levantamento parcial dos mesmos, os colocaram à disposição dos pregadores para o citado uso...imprescindível durante esta vida, para o seu sustento e aquele dos indigentes...".. Cf. também II, cap. XVII, § § 1619, p. 455-459.

35 Defensor da Paz, II, XIV, § 14, p. 392: "Não convém, pois, aos perfeitos, na condição de sucessores de Cristo e dos Apóstolos, manter consigo, quer dizer, em sua propriedade, terras, cidades ou castelos. Nunca, aliás, através do exemplo e da ação deles, foram dadas à Igreja, isto é, aos ministros do Evangelho, uma espécie de possessão sobre os bens imóveis, e tampouco a faculdade de conserválos para o futuro em seu poder efetivo...". 
veram adquirir propriedade e viver dos seus frutos, o que jamais teriam feito se tais atos fossem proibidos, ilícitos e pecaminosos, consoante os ensinamentos do Novo Testamento. Mais tarde, apoiados na mesma fonte, igualmente, os dignitários eclesiásticos aceitaram as doações e as esmolas em dinheiro que o imperador Constantino I e outras pessoas ofertaram, não só à Igreja Romana, mas também às outras igrejas e abadias. Aliás, foi por essa razão também que, às vezes, Jesus e os Apóstolos levavam consigo uma bolsa com dinheiro. Além disso, permeando e fundamentando seu discurso, como de costume, o frade galego alude a uma grande quantidade de passagens do direito canônico.

Enfim, Álvaro Pais conclui suas considerações, afirmando que, por esses motivos, salvo aqueles religiosos que renunciaram ao direito de propriedade sobre os bens em geral, todos os demais clérigos e as igrejas podem licitamente possuir bens e dinheiro. ${ }^{36}$

Quanto à passagem da Epistula ${ }^{37}$ em que o Franciscano Galego tratou desse assunto, constata-se que as idéias são as mesmas, embora a argumentação não

${ }^{36}$ Estado e Pranto da Igreja, vol. III, INIC, Lisboa, 1991, p. 347-349: “...Q. Além disso, a afirmação daquele ímpio doloso e sofista de que a Igreja não pode ter bens temporais é falsa, porque não só os leigos mas também os clérigos podem ter bens temporais e próprio. Porém, ele tirou isto duma antiga heresia. Há, efectivamente, destes hereges que condenam os que têm neste mundo propriedade (Causa XXIV, q. III, cap. Quidam, vers. Apostolici).

Outros há também que dizem que a Igreja não se manteve em estado de salvação desde o tempo do papa Silvestre que recebeu a doação de Constantino, de que fala a Dist. XCVI, cap. Constantinus. Mas nestes a iniqüidade mentiu a si mesma (SalmoS, XXV!), porquanto a Igreja primitiva tinha dinheiro e próprio em comum (Actos, IV e V; Causa XII, q. I, cap. Dilectissimis e capo Scimus). Por isso é que, vendo os sumos sacerdotes e os outros fiéis que era melhor para as igrejas antes terem possessões que dinheiros resultantes da venda das possessões, deram-lhes a posse dos prédios das igrejas (Causa XII, por quase toda a q. II) que ficam em poder dos bispos (Causa XII, q. I, cap. Videntes). Também Cristo teve algumas vezes uma bolsa (João, XII), razão por que a sua Igreja também a havia de ter (Causa XII, q. I, cap. Habebat e cap. Exemplum; Causa XXIII, q. IV, capo Duo ista).

Agora, que os bispos e outros clérigos podem ter próprio, em especial, os que não são religiosos, isso é evidente (Causa XII, q. I, cap. Episcopi, com os 2 cap. seg., e os $\S \S$ Cum ergo e Ostensun, e o cap. Illi, e q. II, cap. Monemus onde diz "Seja compelido a entregar»; Causa I, q. II, cap. Clericus e cap. Pastor; Causa XII, q. III, cap. I, e q. IV, cap. úIt.; e Decretais, De testamentis, cap. I e cap. Cum in officiis).

Item, se os santos mártires e confessores, prelados na Igreja de Deus, soubessem que era pecado a Igreja possuir bens temporais, nunca teriam aceitado e administrado as doações de tais bens. Assim argumenta Próspero, como se vê na Causa XII, q. I, cap. Expedit; argumento semelhante na Causa VII, q. I, cap. Omnis qui gemebat.

Além disso, os filhos de Levi que prefiguram os clérigos (Dist. XXI, § I) tinham terras e cidades e possuíam alguns outros bens próprios (Causa XIII, q. I, § Ris ita).

E mais não alego, porque esta é uma heresia manifesta. Sobre isto também escrevi acima no art. XL, verso Item, é erro..."

${ }_{37}$ Op. cit., 112, "§ 15 - "Por outro lado, o que diz aquele matreiro, a saber, que a Igreja não pode possuir bens temporais, é uma mentira.

Na verdade, a Igreja Primitiva possuía riquezas em comum, que eram transformadas, pois os cristãos vendiam as propriedades, e o dinheiro obtido com as mesmas, punham diante dos pés dos Apóstolos, e ela vivia em comum dessas riquezas.

Mas os santos sucessores dos Apóstolos, vendo que era mais útil às igrejas possuir bens do que o dinheiro, e viver do fruto dos mesmos, transformaram o dinheiro em bens. Também, por causa desse motivo, de acordo com o ensinamento de Agostinho, Cristo levava consigo uma bolsa, porque a 
tenha o aparato canonístico que se vê no texto mais recente, de modo que podemos afirmar não ter havido acréscimos ou inovações doutrinais no Artigo 68 em exame.

A 5 $5^{a}$ das teses heréticas imputadas pelo Bispo de Silves a Marsílio de Pádua é "que Cristo, quando subiu aos céus, não deixou vigário..." na Terra. Noutras palavras, essa proposição nega a doutrina do primado de Pedro sobre os Apóstolos e discípulos, e dos papas, sucessores do Apóstolo, sobre os dignitários e eclesiásticos e o clero em geral.

Marsílio por igual discorre longamente sobre esses assuntos na $2^{\underline{a}}$ Parte de seu tratado. O ponto de partida para ele negar a commissio Petri se apóia obviamente na tese, segundo a qual ele dizia ter havido uma igualdade entre todos os Apóstolos, no que respeita ao caráter essencial inerente ao Sacramento da Ordem.

Ademais, reiteramos novamente que a teoria política do Paduano acerca da organização do Estado e do supremo poder governamental unitário do mesmo, formulada na Primeira parte do Defensor da Paz, lhe impunha contestar a existência e a legitimidade de qualquer outro poder paralelo, ainda mais naquela ocasião específica em que, duma parte, João XXII não tinha reconhecido a eleição imperial de 1314, mediante a qual Ludovico IV ascendera ao trono imperial e, de outra, a teoria política hierocrata, formulada e explicitada, alguns decênios antes, por renomados teólogos, como Egídio Romano OSA, em seu livro Sobre o poder eclesiástico, e Tiago de Viterbo OSA, no seu tratado De regimine christiano (1301), que atribuíam ao papa a suserania universal nas esferas espiritual e secular.

À parte essas observações preliminares, a doutrina do Paduano, que se alicerça em argumentos teológicos, ou de razão teológica, ou histórico-canônicos, pode ser resumida nos seguintes tópicos mais importantes: (a) as frases proferidas por Jesus Cristo e dirigidas particularmente a Pedro não são suficientes para justificar que ele tivesse recebido o primado do Filho de Deus e o exercido sobre os demais Apóstolos. ${ }^{38}$ (b) Por isso, os sucessores de Pedro, os Bispos de Roma, não podem

sua Igreja igualmente haveria de a ter. Daí, igualmente, as Leis e os Cânones aduzirem acerca dos bens dos eclesiásticos privilegiados pelos imperadores. Ademais, Constantino dotou a Igreja com muitos bens, e semelhantemente assim o fizeram outros imperadores após ele. E São Silvestre [113] e outros Pontífices Romanos, santos e mártires, bem como outros santos prelados da Igreja receberam bens em doação, o que não teriam feito, tanto eles quanto os doadores, se isso fosse pecado. Ora, negar que a Igreja possa possuir bens temporais é uma antiga heresia, que foi ressuscitada por esse novo herege e com ele condenada...".

38 Cf. Defensor da Paz II, XV e XVI, na íntegra, p. 407-438. Com o fito de abreviar, não transcrevemos nem os parágrafos mais relevantes desses capítulos. Cf. também II, XXVIII, § § 5-8, p. 616-621. Um pouco mais adiante, no $\S 25$, p. 654, Marsílio arremata suas considerações afirmando o seguinte: "Quanto às opiniões dos santos e dos doutores, especialmente no que concernem àquela passagem da Escritura que se encontra no Evangelho de Mateus, capítulo XVI: "Tu és Pedro e sobre esta pedra', e àquela outra que se acha no Evangelho de Lucas, capítulo XXII: 'Eu roguei por ti, Pedro,', e ainda, àquela que está escrita no Evangelho de João, capítulo XXI: 'Se tu me amas, apascenta as minhas ovelhas', as quais eles explicam dizendo que Cristo conferiu imediatamente a São Pedro uma autoridade ou poder sobre os outros Apóstolos, chamando-o de 'príncipe dos Apóstolos e pastor universal', e alguns deles ainda o designam por 'cabeça da Igreja', é preciso rebatê-las, com todo respeito, afirmando que Cristo não conferiu imediatamente a São Pedro a autoridade essencial, que chamamos de sacerdotal, nem a preeminência acidental do pastoreio sobre os demais Apósto- 
alegá-las como fundamento para exercerem tal autoridade sobre os demais membros do clero, $^{39}$ muito menos sobre qualquer leigo, mormente no tocante aos governantes seculares. (c) Admitindo-se a hipótese de que Pedro tenha exercido esse primado sobre os outros Apóstolos, ele foi-lhe atribuído exclusivamente por intermédio da escolha efetuada pelos mesmos. ${ }^{40}$ (d) O Primado da Igreja Romana sobre

los, mas que ele a descartou de Pedro e de cada um dos outros, no tocante a exercê-la reciprocamente, conforme o mostramos em detalhes através da Escritura e dos comentários dos santos e doutores no capítulo $16^{\circ}$ desta Parte do tratado, e de certo modo o reiteramos no princípio deste capítulo...".

39 Ibidem, II, XV, § 7, p. 414: “....Por esse motivo é que o Bispo de Roma não possui maior autoridade sacerdotal essencial do que qualquer outro antístite, da mesma forma como São Pedro não a teve em relação aos outros Apóstolos. Na verdade, todos receberam a mesma autoridade de Cristo, numa proporção equivalente e de modo imediato, como o demonstramos anteriormente, baseados no peso da opinião de Jerônimo, ao comentar aquela frase do Evangelho de Mateus, capítulo XVI [19] : 'Eu te darei as chaves do reino dos céus'...".

p. 414: § 8 - Por sinal, São Jerônimo também externou tal pensamento verídico naquela Epístola antes citada, na qual, após ter comprovado mediante as inúmeras citações das palavras dos Apóstolos já referidas, que na Igreja Primitiva, durante a Era Apostólica, não havia nenhuma diferença entre o presbítero e o bispo quanto à dignidade essencial conferida por Cristo, apresentando a seu favor o seguinte argumento: 'Na verdade, uma pessoa tinha sido eleita e colocada à frente das outras, para remediar os cismas, por receio de que alguém, arrebatando o poder para si, dividisse a Igreja de Cristo. Por isso, em Alexandria, desde a época de Marcos Evangelista até a de Heridas e Dionísio, bispos, os presbíteros sempre elegeram um dentre eles para ocupar o lugar mais importante, e o designavam bispo, tal qual o exército fazia ao escolher o seu imperador', (preceptor ou capitão segundo o uso moderno do termo, não conforme o significado dessa palavra, designando o monarca, como atualmente é empregada) ou como os diáconos elegiam um dentre eles, de reputação industriosa, e o nomeavam arcediago. 'Ora, além das tarefas relativas à organização eclesiástica, o que faz um bispo que um presbítero não possa fazer?', [S. Jerônimo, Epístola a Evangelo, PL XXII: 1194] quanto aos atos dependentes da autoridade essencial do sacerdócio. Cf., igualmente, II, XXVIII § 26, p. 655: "Com efeito, quem não fica admirado com o fato de que, os Apóstolos discutindo entre si para saber qual deles era o maior, sempre ouviram de Cristo que eram iguais e que nenhum deles possuía uma autoridade preeminente sobre os outros... Por que Cristo não ordenou aos demais Apóstolos se subordinarem a Pedro no cargo pastoral, ocultando a eles e aos seus um ministério tão relevante como o de ser a cabeça da Igreja? Porque não encontramos em passo algum da Escritura que tal ordem foi dada aos Apóstolos? Por que motivo então, Pedro teria dado a mão a Paulo em sinal de comunhão? Se eles não fossem iguais entre si, ao contrário, Pedro lhe teria dado uma ordem, visto que era o seu superior. Numa palavra, em toda a Escritura, onde há referência à questão em apreço,alude abertamente ao contrário da opinião sustentada por esses glosadores.

Mas admitamos a hipótese, a qual, aliás, mantendo-se fiel à Escritura, temos de maneira sistemática negado, que o cuidado pastoral dos outros Apóstolos tenha sido confiado imediatamente por Cristo a São Pedro. Entretanto, não é por esse motivo que se pode comprovar que, após a morte do Apóstolo, o Bispo de Roma, ou um outro tivessem de ser o pastor dos demais, graças a uma disposição imediata de Cristo. Ao contrário, tal autoridade compete a qualquer um, mediante uma escolha humana imediata, como antes o demonstramos nos capítulos 16ำ $17^{\circ}$ e $22^{\circ}$ desta Parte....".

40 Ibidem, II, XVI, § 4, p. 423: “...Portanto, nem Pedro, e tampouco um outro Apóstolo, e ainda uma outra pessoa qualquer não escolheram Paulo para exercer o ministério da Palavra, nem o enviaram e muito menos lhe ordenaram que pregasse o Evangelho,...Logo, Pedro não recebeu imediatamente de Deus um poder maior que o dos outros Apóstolos, poder esse que lhe assegurava uma preeminência sobre eles, e muito menos a jurisdição coerciva para estabelecê-los no ofício sacerdotal,...A única coisa que seguramente pode admitir-se é que Pedro foi o primeiro em relação aos demais por causa de sua idade, ou talvez devido ao tempo que ele dedicou ao seu cargo, ou quiçá em virtude da eleição efetuada pelos Apóstolos, que o reverenciavam apropriadamente pelos motivos citados, embora ninguém possa demonstrar mediante a Escritura Sagrada que essa escolha tenha efetivamente acontecido". 
as demais igrejas foi outorgado por Constantino I, ato esse político, efetivado por quem tinha competência para tanto. ${ }^{41}$

Enfim, passemos ao exame e à análise do trecho do Art. 68 sobre a última proposição atribuída a Marsílio de Pádua.

Para começar, Frei Álvaro qualifica-a como mentirosa e carente de fundamento e passa a refutá-la, aludindo ao conhecido trecho do Evangelho de São João, capítulo 21[17-19], em que, após sua Ressurreição e antes de ascender ao céu, Jesus confia a Pedro a liderança, o pastoreio de suas ovelhas e de seus cordeiros, que representam os discípulos e os apóstolos e, na pessoa dele, aos seus sucessores, os Pontífices Romanos, o governo da Igreja. A assertiva principal, um argumento teológico, é corroborada com uma grande quantidade de citações tiradas de textos de direito eclesiástico, em especial das Decretais de Gregório IX (1234),

$\S 5$, p. 423: "A prova de que estamos falando a verdade se apóia no fato de que não há, em trecho algum da Sagrada Escritura, nenhuma referência a que são Pedro tenha exercido qualquer autoridade especial sobre os outros Apóstolos, mas, ao contrário, que ele se manteve sempre como os demais. De fato, ele não se arrogou a incumbência de resolver as questões relativas à pregação do $E$ vangelho envolvendo a doutrina. Essas questões,no entanto, eram solucionadas através duma troca de idéias em comum entre os Apóstolos e os outros fiéis mais sábios, e não pela decisão de Pedro nem dum outro Apóstolo...". Ibidem, II, XVI, § 12, p. 430: "Se, no entanto, os Apóstolos tivessem escolhido São Pedro como bispo ou chefe por causa de sua idade e da excepcional santidade que já tinha adquirido, conforme se lê num decreto do Papa Anacleto, que se encontra no Código Isidoriano, do qual tiramos esta citação: 'Os outros Apóstolos receberam poder e honra igual a ele'. Pedro, 'todavia, quiseram que fosse o seu chefe'. [Pseudo-Isidoro, Decretais, Anacletus (2) cap. XXIV (ed. Hinschius): 79], disto, entretanto, não decorre que, os sucessores de Pedro na Sé Romana, ou ainda se fossem bispos alhures, haveriam de ter e exercer uma preeminência sobre os sucessores dos demais Apóstolos, pois alguns deles foram mais virtuosos do que determinados sucessores de São Pedro, e, falando apropriadamente, todo bispo é sucessor de todo Apóstolo quanto ao ministério, mas não quanto ao lugar em que se encontra a sé episcopal. Além disso, por que essa preeminência caberia mais aos sucessores de São Pedro na Sé Romana do que àqueles outros nos bispados de Antioquia, de Jerusalém ou alhures, se ele foi bispo em muitas cidades?...".

${ }^{41}$ Defensor da Paz II, XI § 8, p. 337: "O que dissemos, é confirmado pelos Decretos ou Histórias dos Pontífices Romanos. Aí se menciona um privilégio concedido pelo Imperador Romano Constantino, privilégio esse que, segundo os autores de tais textos, ele atribuiu ao bem-aventurado Silvestre, Pontífice Romano, dando-lhe uma jurisdição coerciva sobre todas as igrejas do mundo e sobre os demais bispos ou presbiteros.

Como todo Papa Romano, e em conseqüência, toda comunidade dos padres e bispos declara que esta doação tem um valor de direito, então devem logicamente admitir que Constantino, ele mesmo, anteriormente possuiu e exerceu sobre eles esta jurisdição ou poder, especialmente considerando-se que, por força das palavras da Escritura, não lhes compete exercer nenhuma jurisdição desse tipo sobre ninguém, clérigo ou leigo...". Cf., também II, XVIII, § 5-7, p. 463-466; II, XXII § 10, p. 514: "Que o citado poder, ao qual aludimos há pouco, seja da competência do legislador humano cristão, é um fato confirmado através dum edito de Constantino I, Imperador dos Romanos, inserido no Código Isidoriano [Pseudo-Isidoro, Decretais, ed. Hinschius: 252], que contém, entre outras, a seguinte passagem: 'Nós', isto é, o Imperador Romano, 'decretamos que ela detenha a preeminência', a Igreja Romana, 'não apenas sobre as quatro principais Sés, a de Antioquia, a de Alexandria, a de Jerusalém e a de Constantinopla, mas ainda sobre todas as igrejas de Deus, espalhadas pelo mundo.E que a pessoa que nesta ocasião se encontrar à frente da Sacrossanta Igreja Romana, na condição de Pontífice, deva ser a mais importante e o chefe dos demais sacerdotes de todo o universo, e tudo o que concerne ao culto divino e à manutenção da estabilidade da fé, venha a ser decidido mediante seu julgamento'..."; Ibidem, II, XXVIII § 12, p. 628: “...Na verdade, a Igreja Romana foi estabelecida à frente das demais, através de decretos dos Príncipes Romanos e com a anuência das outras igrejas, como se fosse uma escolha...".; cf., também, II, XXIX, § 10-11, p. 669-672. 
do 6º Livro das Decretais da época de Bonifácio VIII e Clemente V (1305-14) e das Clementinas, do pontificado de João XXII. Para arrematar a primeira parte de seu discurso, o frade galego ainda acrescenta os comentários de renomados canonistas, como João André e o Cardeal Henrique de Segúsio, a algumas daquelas passagens do Direito Canônico.

O frade galego ainda acrescenta à sua argumentação que, por morte do Papa, sobrenaturalmente, Cristo está à frente de sua Igreja e, apenas em alguns aspectos administrativos, só o colégio cardinalício supre a ausência do mesmo, de modo que, absolutamente nunca a Igreja fica acéfala. ${ }^{42}$

Na segunda parte de seu arrazoado, inicialmente, Frei Álvaro demonstra que São Pedro primeiramente exerceu o seu múnus em Antioquia e, consoante uma antiga tradição, por ordem de Jesus Cristo, depois, exerceu-o em Roma, para onde se mudou. Em seguida, igualmente, com base na tradição e no Direito Canônico, afirma que o próprio São Pedro escolheu São Clemente Romano para o suceder e que, mais tarde, outros papas sucederam o Príncipe dos Apóstolos e assim haverá

42 Estado e Pranto da Igreja, vol. III, INIC, Lisboa, 1991, p. 349-351: “...Finalmente, a afirmação do dito herege Marsílio de que Cristo, quando subiu aos céus, não deixou vigário, é falsa e herética, porque é tornar a Igreja acéfala, isto é, deixá-la sem cabeça, contra o exposto no cap. Nulla da Dist. XCIII, e porque deixou em seu lugar Pedro e sucessores, a quem disse: Apascenta as minhas ovelhas (João, últ.). Efectivamente, todos os pontífices romanos são sucessores de Pedro e representam a sua pessoa. Por isso, assim como a Pedro, assim também a qualquer dos seus sucessores Cristo disse aquelas palavras, como vem expresso nas Decretais, tit. De maioritate et oboedientia, cap. Solitae, § Nos autem, e tit. De translatione episcopi, cap. Quanto, onde diz 'só a S. Pedro e por meio dele a seus sucessores' e 'O pontífice romano que faz na terra as vezes, não de um simples homem, mas do verdadeiro Deus'; no cap. Licet: 'o qual é sucessor de Pedro e vigário de Jesus Cristo'; nas Decretais, Vt ecclesiastica beneficia, cap. Vt nostrum, onde vem 'visto que embora tenhamos na terra $o$ lugar de Deus'; nas Decretais do Liv. 6o , De electione, cap. Vbi periculum, § Caeterum, onde diz 'quando se trata da criação do vigário de Jesus Cristo sucessor de Pedro', e no cap. Fundamenta, § Decet, do Liv. 6o que diz 'do vigário de Deus o pontífice romano'. E está expressíssimo nas Decretais do Liv. 6o De homicidio, cap. Pro humani, 1a resposta: 'O Filho de Deus, Jesus Cristo, para, ao subir ao Pai após a ressurreição, não deixar sem pastor o rebanho redimido pelo preço do seu glorioso sangue, cometeu ao apóstolo S. Pedro o cuidado deste rebanho, para que firmasse os outros, com a solidez da sua fé, na religião cristã e acendesse os espíritos deles com o ardor da devoção para as obras da sua salvação'; e abaixo "Nós feitos, por disposição do Senhor, sucessores, embora imerecidamente, do mesmo apóstolo, e ocupando, posto que indignamente, o lugar do próprio Redentor na terra». Por isso, diz a glosa de João André à palavra desereret (deixar) desse texto: 'Por esta palavra fica assaz evidente que o poder de Pedro passou aos sucessores; doutro modo, depois de Pedro, a Igreja teria ficado sem pastor e sem cabeça, o que é falso' (Decretais, De officio ordinarii, cap. Quoniam). A isto faz a Dist. XL, cap. Non nos: 'Nós não julgamos, como dizeis, que S. Pedro e os seus sucessores receberam do Senhor, com os privilégios do trono, a licença de pecar. Ele com a herança da inocência transmitiu aos pósteros o dote perene dos merecimentos, etc. '. E até, vagando a Igreja, por morte do papa, não se deve dizer que fica sem cabeça, porque tal asserção não estaria longe de heresia, visto que então o corpo dos cardeais e toda a Igreja tem a cabeça geral da Igreja, a saber, o vero e próprio Cristo vivo (De consecratione, Dist. II, cap. Prima, no fim; para isto veja-se a Dist. XXII, cap. I e II). Também então lhe sucede o colégio dos cardeais em certas coisas (Decretais do Liv. 6o, De electione, cap. Vbi periculum, § Idem quoque, e Clementinas, De electione, cap. Ne romani, § Eo tamen; e assim também o nota o Ostiense às Decretais, De poenitentiis et remissionibus, cap. Cum ex eo, no fim, e após ele João André às Decretais, De schismaticis, cap. I, na glosa Non arg.)". 
de acontecer até ao final dos tempos, porque o Papa é o vigário de Cristo e esposo visível da Igreja na terra. ${ }^{43}$

Esse mesmo tema Frei Álvaro também abordou num passo da mencionada Epistula ad quosdam cardinales ${ }^{44}$ Cotejando ambas as passagens, de imediato, se nota que nessa Carta o Menorita galego é bastante sucinto e que sua refutação estriba-se em três pilares.

O primeiro deles é um argumento teológico que se apóia quase nas mesmas frases de Jesus Cristo dirigidas a Pedro, referentes ao primatus et comissio Petri, entre outras, aquela que referimos antes, e que se encontra no Evangelho de João, 21, 17-19.

O segundo é de natureza histórica. Álvaro abreviadamente fala sobre a escolha de Clemente I efetuada pelo próprio São Pedro, o qual, antes de ser bispo em Roma, o foi em Antioquia.

No terceiro argumento, o frade galego refuta aquela proposição, de um lado, recorrendo à via do absurdo e, de outro, a argumentos de razão teológica. Com efeito, é um absurdo pensar que Jesus fez coisas inutilmente. De fato, tendo fundado a Igreja e a confiado a Pedro e aos seus sucessores, a fim de, no decorrer dos séculos, até ao Juízo Final, dar continuidade ao anúncio da Boa Nova e da salvação dos homens, após sua ascensão aos céus, seria uma incongruência pensar que ia deixá-la sem um chefe visível. Se isso fosse verossímil então não haveria

43 Ibidem, p. 351: "Item, S. Pedro, após a ascensão do Senhor, regeu primeiro a Igreja de Antioquia, e então era esta a cabeça; depois, a sua sede foi transferida para Roma, por mandado do Senhor (Causa XXIV, q. I, cap. Rogamus), e o próprio Pedro instituiu para lhe suceder Clemente (Causa VIII, q. I, cap. Si Petrus, cap. Oportet e cap. Clemens), e, em seguida, sucederam por eleição os pontífices romanos até aos nossos tempos, e sucederão até ao Dia do Juízo no lugar de Cristo, porque a Igreja, que é o corpo de Cristo, não pode ser nenhuma morta, sem cabeça. Para isto faz optimamente a Causa XXIV, q. I, cap. Pudenda, no fim: 'por forma que, não podendo a Igreja ser nenhuma, ela se mantém na raiz da sé apostólica através dos sucessores dos bispos, etc.. .'; e o cap. Didicimus: 'Ora, se a Igreja existiu em Cornélio, que sucedeu por legítima ordenação ao bispo Fabião'.

Por conseguinte, aquele que nega isto, verdadeiramente nega Cristo esposo da Igreja, porque a Igreja nunca foi nem será sem esposo. Mas os hereges divididos em facções, porque atribuem muitos esposos à Igreja, negam o único esposo verdadeiro. Argumento para isto na Causa I, q. III, capo Saluator, vers. Quod vero..."

44 Op. cit. : 113. § 16 "Por último, o que diz aquele ímpio, isto é, que Cristo, quando ascendeu aos céus, não deixou um vigário, também é uma mentira, porque deixou Pedro e os seus sucessores, a quem disse: 'Apascenta as minhas ovelhas' [Jo XXI, 17]. Item dissera no dia da ceia: 'Não vos deixarei órfãos' [Jo XIV, 18]. Item, disse a Pedro: 'Conduz ao largo,' [Lc V, 4], o barco.

Ademais, após a ascensão, Pedro dirigiu a igreja antioquena, depois a romana, e ele próprio estabeleceu Clemente como seu sucessor, e mais tarde, assim aconteceu com os sumos pontífices que foram eleitos.

Além disso, se Cristo não tivesse deixado um vigário, o corpo místico da Igreja não teria uma cabeca na terra, logo, não seria um corpo vivo, mas morto, e, assim, ela não existiria e estaria como morta. Mas essa hipótese é um absurdo, porque a Igreja não pode ser aniquilada, porque Cristo rogou por ela. E o rebanho estaria disperso como se não tivesse pastor, e não haveria obediência na Igreja, dado que não se tinha a quem obedecer, conquanto tenha sido fundada na obediência, reparadora da desobediência do primeiro homem, e recondutora à obediência, através do segundo Adão, Jesus, obediente ao Pai até à morte. Ora, na verdade, quem renega o vigário de Cristo sobre a terra nega o próprio Cristo, porque a Igreja sempre teve e terá um esposo. Entretanto, são os hereges divididos em grupos, que criam para si muitos esposos e para a Igreja, e por isso negam que ela possua um só esposo...". 
Igreja Militante, porque ela, sem pastor visível, já teria desaparecido da face da terra.

Ademais, Cristo fundou a Igreja na sua obediência ao desígnio do Pai, reparando a desobediência de nosso primeiro pai, de modo que, os cismáticos, ao romperem com o Sumo Pontífice, o esposo visível da Igreja, e fundarem as suas próprias igrejinhas, também renegam e desobedecem ao próprio Filho de Deus.

A nosso ver, por conseguinte, a refutação alvarina, contida na mencionada Carta e no Artigo 68, conquanto no aspecto doutrinal se aproximem bastante, no texto cronologicamente anterior é mais profunda do que no outro, embora, como escrevemos, o passo do Artigo 68 esteja repleto de remissões aos textos de direito canônico.

Ao concluir este trabalho, resta dizer que, ao escrever o Artigo 68 do Livro Primeiro do Estado e Pranto da Igreja, embora não tenha feito nenhuma alusão, conforme indicamos, Álvaro Pais apoiou-se basicamente no texto da Epistula ad quosdam cardinales, escrita anteriormente à obra em apreço, para redargüir as proposições que imputou a Marsílio de Pádua. Igualmente, como pudemos verificar e ressaltamos, sob o aspecto do pensamento, ambos os textos são essencialmente idênticos, embora, às vezes, quanto à forma, se note, num ou noutro, ora uma preocupação no tocante a aclarar a doutrina, ora a apresentá-la de maneira mais resumida. Enfim, ele não teve em mãos e muito menos compulsou o Defensor da Paz, tendo acolhido e assumido as conclusões que os censores da obra fizeram e explicitaram na bula Licet iuxta doctrinam de João XXII, de outubro de 1327, na qual foi condenada como herética juntamente com o Médico paduano.

Frei Álvaro voltou novamente a tratar de três dessas cinco proposições, em seu Colírio da fé contra as heresias, escrito por volta de $1344 .{ }^{45}$

\footnotetext{
Cf. ed. bilíngüe e tradução feita por Miguel Pinto de MENESES, 2 vols., Lisboa, Inst. de Alta Cultura da Faculdade de Letras, 1954, 1956. Vol. II, p. 25-34. Cf. também José Antônio de C.R. de SOUZA, Álvaro Pais O. Min. (1270-1349) Marsílio de Pádua (1280-1342) e o Colírio da Fé contra as Heresias, Veritas 187 (2002): 407-424.
} 